\title{
Revision of the Portuguese catalog of tsunamis
}

\author{
M. A. Baptista ${ }^{1}$ and J. M. Miranda ${ }^{2}$ \\ ${ }^{1}$ Instituto Superior Engenharia de Lisboa, CGUL, IDL, Lisboa, Portugal \\ ${ }^{2}$ University of Lisbon, CGUL, IDL, Lisbon, Portugal
}

Received: 19 August 2008 - Revised: 19 November 2008 - Accepted: 28 November 2008 - Published: 9 January 2009

\begin{abstract}
Catastrophic tsunamis are described in historical sources for all regions around the Gulf of Cadiz, at least since $60 \mathrm{BC}$. Most of the known events are associated with moderate to large earthquakes and among them the better studied is 1 November 1755 . We present here a review of the events which effects, on the coasts of the Portuguese mainland and Madeira Island, are well described in historical documents or have been measured by tide gauges since the installation of these instruments. For a few we include new relevant information for the assessment of the tsunami generation or effects, and we discard events that are included in existing compilations but are not supported by quality historical sources or instrumental records. We quote the most relevant quantitative descriptions of tsunami effects on the Portuguese coast, including in all pertinent cases a critical review of the coeval sources, to establish a homogenous event list. When available, instrumental information is presented. We complement all this information with a summary of the conclusions established by paleo-tsunami research.
\end{abstract}

\section{Introduction}

Catastrophic tsunamis are described in historical records related with all countries around the Gulf of Cadiz (El Mrabet, 1991; Campos, 1992; Baptista et al., 1998a), a key tsunami prone area in Europe associated with the western segment of the Eurasia-Nubia plate boundary. Tsunami events are a consequence of the compressive tectonic environment of the Ibero-Maghrebian area (Baptista et al., 1998b; Zitellini et al., 2001; Gracia et al., 2002; Gutscher et al., 2006), the transcurrent motion along the Gloria Fault and surrounding area (Kaabouben et al., 2008) or the effect of far away sources (e.g. Azores or Grand Banks). Events generated within the

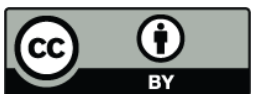

Correspondence to: M. A. Baptista (mabaptista@dec.isel.ipl.pt)
Gulf of Cadiz affect a large area, particularly SW Portugal, South Spain and Morocco; the largest ones affect the SW Irish and UK coasts and the Caribbean (e.g. Haslet and Bryant, 2008).

The oldest catalog of earthquakes and tsunamis written in Portuguese is called "Historia Universal dos Terramotos que tem havido no mundo de que há noticia desde a sua criação até ao século presente" (Universal History of Earthquakes occurred around the world, since its creation up to the current century) published by Mendonça (1758). This book refers to previous written Portuguese sources such as Brito (1597) and Sousa (1678) that are themselves compilations of historical facts where earthquakes and tsunamis are reported among other miscellaneous events, as written Portuguese sources prior to the fourteenth century are rather scarce. Mendonça (1758) devotes part of his book to the 1755 event and its aftershock sequence. For all events prior to 1755 we also extensively considered the answers to the Marques de Pombal inquiry, question ten: "Do you remember other earthquakes in the past, at your place, and what damage it caused?" Most answers were transcribed directly from the Arquivos do Ministério do Reino (1756) by Runa and Freire (1991).

The second relevant compilation was written by Perrey (1847), and is called "Sur les Tremblements de Terre de la Peninsule Iberique" (About Earthquakes in the Iberian Peninsula). Perrey (1847) often quotes Mendonça (1758) for the Portuguese events but in some cases he gives information on original sources which were obtained and cross checked. A few years after Perrey, Robert Mallet (1852) presented a new catalog of earthquakes between $1606 \mathrm{BC}$ and $1850 \mathrm{AD}$ where several historical events are reviewed.

Rodriguez (1932) published the first modern catalog of seismic events for Iberia, where several tsunami events are described. Heck (1947) published a list of seismic sea waves where the events of 27 December 1722, 1 November 1755 and 31 March 1761 are included, but mainly based on Mallet (1852) descriptions. Berninghausen (1964) published

Published by Copernicus Publications on behalf of the European Geosciences Union. 
a list of tsunamis and seismic seiches for eastern Atlantic south of the Bay of Biscay, in the Bulletin of Seimological Society of America; this compilation starts with the 26 January 1531 event and does not consider any previous tsunami event. This list includes, among others, events on 26 December 1746, 28 April 1758 and 4 July 1809. These events, not included in the GITEC catalog (Tinti et al., 1999) are analysed here. For the aftershock sequence of the 1755 earthquake the author reports only one tsunami event (29 March 1756), as we do. We must also refer the pioneering work of Moreira (1968) that also gathered a number of mareographic records, some of them used here.

Most major tsunamis are known only from historical sources. In recent times, the press is also an important source of information, particularly in what concerns flooding and harbor effects. Descriptions presented here come from coeval sources except for the events prior to 1500, due to the fact that these sources are quite rare in Portugal. After 1881 we have access to tsunami instrumental data in the Portuguese coasts: the first Portuguese tide station was installed at Cascais in 1881 and the second one at Lagos in 1908. All tide records from these stations were checked for tsunami effects related with $M>6$ seismic events in the SW Iberian margin. In particular tide records of Cascais and Lagos were obtained for the events of 25 November 1941, 28 February 1969 (Gjevik et al., 1997), 26 May 1975 (Kaabouben et al., 2008), and 1 January 1980. Mareograms obtained in the Portuguese tide gauge network have also been used for the 1929 Grand Banks tsunami (Fine et al., 2005). Unfortunately no stations were operating during the Cadiz earthquake of 1964 and so we cannot evaluate its effect on the Portuguese coasts. In some cases, complementary tide gauge stations installed at Portuguese harbors (e.g. Leixões) were also used to assess tsunami effects.

Very large non-seismic tsunamis have been evoked as a possible source of tsunami hazard in Portugal (e.g. Ward and Day, 2001) but up to now their effects on the Portuguese coasts have not been proved either by instruments, historical documents or sedimentary record. However, we consider as non-seismic events the 1930 rock fall in Madeira Islands, which effects are described in this work, and the 1929 Grand Banks tsunami that was recorded in the Azores and Leixões (close to Oporto, northern Portugal). There are some additional evidences for other non-seismic events but their identification in historical records is up to now inconclusive.

In this work we discuss only the events that produced effects on the Portuguese mainland coasts. In this sense, we do not consider those generated in the Azores plateau and only recorded there, which have been the object of a recent publication by Andrade et al. (2006). All locations are complemented with their geographical coordinates (cf. Table 1), to allow the use of tsunami historical information by non Portuguese researchers. In what concerns the 1 November 1755 tsunami the descriptions are summarized, because it has been the subject of a number of previous works (Solares et al., 1979, 2004; Baptista et al., 1998a, b); however, a list of tsunami effects is included in the present study, as complementary information to support hazard studies. A similar situation arises in what concerns the 27 December 1722, the 31 March 1761 and the 26 May 1975 events.

\section{Description of the historical events}

\subsection{The 60 BC Portugal and Galicia tsunami}

The $M=8.5$ earthquake dated $60 \mathrm{BC}$ is the oldest event often considered in Portuguese earthquake catalogs (LNEC, 1986; Sousa et al., 1992; Martins and Victor, 2001). Sousa (1678) gives one of the rare descriptions of the tsunami: "[...] About these years, or slightly before, took place that remarkable earthquake on the coasts of Portugal and Galicia, with which many places were ruined [...]. And the sea leaving in some places its ordinary limits occupied a part of the land, uncovering it in other places where it was never seen before [...] At Cape St. Vincent a bull gave birth to a mare [...]. Very sad augury to the coasts of Lusitania, this monster, in the opinion of the professors [...]". Mendonça (1758) reports this event but only quoting Sousa (1678).

\subsection{The 382 AD Cape St. Vincent tsunami}

The $382 \mathrm{AD}$ tsunami is briefly described by Brito (1597): "[...] the rise of the sea subverted a part of the land and overtopped some islands [...] of which some rocks remained in the middle of the sea, which can be seen close or inside the ocean, mainly in Cape St. Vincent [...]". The Martins and Victor (2001) catalog evaluates the magnitude of the corresponding earthquake as 7.5.

\subsection{The 26 January 1531 Tagus Estuary tsunami}

On the 26 January 1531, between 4 and 5 a.m., a strong shock was felt in Lisbon and along the Tagus Valley. The shock heavily destroyed Lisbon downtown and neighbouring areas, causing approximately 1000 casualties (Vogt, 1985; Justo and Salwa, 1998). The downtown of Lisbon and several dwellings along estuary were flooded by the river and ships in the harbour were left in dry. The maximum reported earthquake intensity is $X$ (MSK) making it one of the most disastrous earthquakes in the history of Portugal. Approximate epicentre coordinates inferred from the macroseismic field are $38.9^{\circ} \mathrm{N}, 9.0^{\circ} \mathrm{W}$ (Martins and Victor, 2001) but its tectonic source remained uncertain. Justo and Salwa (1998) locate it NE of Lisbon, up Tagus estuary and it was probably generated north of the Tagus Estuary close to Vila Franca de Xira town $\left(-9^{\circ} \mathrm{E}, 38.9^{\circ} \mathrm{N}\right)$.

The description of a large tempest in the sea is often repeated: "[...] several vessels were swallowed by the pits of the grown and turbulent sea [...]" (Laurent Surius, 1567; Babinet, 1861); "Many ships submerged with the tempest 
Table 1. Geographical coordinates of the locations included in the text.

\begin{tabular}{|c|c|c|c|c|c|}
\hline Location & Longitude & Latitude & Location & Longitude & Latitude \\
\hline Adra & $-3.017^{\circ} \mathrm{E}$ & $36.750^{\circ} \mathrm{N}$ & Lagos & $-8.673^{\circ} \mathrm{E}$ & $37.102^{\circ} \mathrm{N}$ \\
\hline Águeda & $-8.448^{\circ} \mathrm{E}$ & $40.574^{\circ} \mathrm{N}$ & Machico & $-16.764^{\circ} \mathrm{E}$ & $32.718^{\circ} \mathrm{N}$ \\
\hline Alandroal & $-7.400^{\circ} \mathrm{E}$ & $38.533^{\circ} \mathrm{N}$ & Malaga & $-4.417^{\circ} \mathrm{E}$ & $36.717^{\circ} \mathrm{N}$ \\
\hline Albufeira & $-8.252^{\circ} \mathrm{E}$ & $37.089^{\circ} \mathrm{N}$ & Matosinhos & $-8.680^{\circ} \mathrm{E}$ & $41.183^{\circ} \mathrm{N}$ \\
\hline Angra (Terceira) & $-27.217^{\circ} \mathrm{E}$ & $38.650^{\circ} \mathrm{N}$ & Monte Gordo & $-7.449^{\circ} \mathrm{E}$ & $37.182^{\circ} \mathrm{N}$ \\
\hline Assumar & $-7.383^{\circ} \mathrm{E}$ & $39.133^{\circ} \mathrm{N}$ & Mount's bay & $-5.525^{\circ} \mathrm{E}$ & $50.129^{\circ} \mathrm{N}$ \\
\hline Aveiro & $-8.654^{\circ} \mathrm{E}$ & $40.641^{\circ} \mathrm{N}$ & Newlyn & $-5.547^{\circ} \mathrm{E}$ & $50.105^{\circ} \mathrm{N}$ \\
\hline Ayamonte & $-7.410^{\circ} \mathrm{E}$ & $37.215^{\circ} \mathrm{N}$ & Oporto & $-8.610^{\circ} \mathrm{E}$ & $41.150^{\circ} \mathrm{N}$ \\
\hline Barcelona & $2.170^{\circ} \mathrm{E}$ & $41.388^{\circ} \mathrm{N}$ & Penzance & $-5.528^{\circ} \mathrm{E}$ & $50.118^{\circ} \mathrm{N}$ \\
\hline Benavente & $-8.820^{\circ} \mathrm{E}$ & $38.978^{\circ} \mathrm{N}$ & Pombal & $-8.627^{\circ} \mathrm{E}$ & $39.914^{\circ} \mathrm{N}$ \\
\hline Buarcos & $-8.883^{\circ} \mathrm{E}$ & $40.167^{\circ} \mathrm{N}$ & Ponta Delgada & $-25.670^{\circ} \mathrm{E}$ & $37.738^{\circ} \mathrm{N}$ \\
\hline Cabo Ruivo & $-9.097^{\circ} \mathrm{E}$ & $38.750^{\circ} \mathrm{N}$ & Pontinha (Madeira) & $-16.918^{\circ} \mathrm{E}$ & $32.641^{\circ} \mathrm{N}$ \\
\hline Cacilhas & $-9.149^{\circ} \mathrm{E}$ & $38.686^{\circ} \mathrm{N}$ & Porto da Cruz & $-16.819^{\circ} \mathrm{E}$ & $32.767^{\circ} \mathrm{N}$ \\
\hline Cadiz & $-6.292^{\circ} \mathrm{E}$ & $36.530^{\circ} \mathrm{N}$ & Porto Santo & $-16.332^{\circ} \mathrm{E}$ & $33.059^{\circ} \mathrm{N}$ \\
\hline Casablanca & $-7.632^{\circ} \mathrm{E}$ & $33.605^{\circ} \mathrm{N}$ & Puerto de Santa Maria & $-6.228^{\circ} \mathrm{E}$ & $36.597^{\circ} \mathrm{N}$ \\
\hline Cascais & $-9.422^{\circ} \mathrm{E}$ & $38.697^{\circ} \mathrm{N}$ & Punta Umbria & $-6.967^{\circ} \mathrm{E}$ & $37.182^{\circ} \mathrm{N}$ \\
\hline Castro Marim & $-7.445^{\circ} \mathrm{E}$ & $37.217^{\circ} \mathrm{N}$ & Quarteira & $-8.104^{\circ} \mathrm{E}$ & $37.068^{\circ} \mathrm{N}$ \\
\hline Coimbra & $-8.429^{\circ} \mathrm{E}$ & $40.211^{\circ} \mathrm{N}$ & Santa Cruz de Tenerife & $-16.255^{\circ} \mathrm{E}$ & $28.470^{\circ} \mathrm{N}$ \\
\hline Conceição de Tavira & $-7.605^{\circ} \mathrm{E}$ & $37.146^{\circ} \mathrm{N}$ & S Jorge (Azores) & $-28.053^{\circ} \mathrm{E}$ & $38.645^{\circ} \mathrm{N}$ \\
\hline Doñana spit & $-6.589^{\circ}, \mathrm{E}$ & $37.018^{\circ} \mathrm{N}$ & Santiago de Compostella & $-8.544^{\circ} \mathrm{E}$ & $42.878^{\circ} \mathrm{N}$ \\
\hline Douro embankment & $-8.669^{\circ} \mathrm{E}$ & $41.137^{\circ} \mathrm{N}$ & Cape St. Vincent & $-8.994^{\circ} \mathrm{E}$ & $37.025^{\circ} \mathrm{N}$ \\
\hline Espinhel & $-08^{\circ} 29^{\prime} \mathrm{E}$ & $40^{\circ} 34^{\prime} \mathrm{N}$ & Scilly Island & $-6.323^{\circ} \mathrm{E}$ & $49.936^{\circ} \mathrm{N}$ \\
\hline Faro & $-7.935^{\circ} \mathrm{E}$ & $37.015^{\circ} \mathrm{N}$ & Setúbal & $-8.893^{\circ} \mathrm{E}$ & $38.525^{\circ} \mathrm{N}$ \\
\hline Figueira da Foz & $-8.851^{\circ} \mathrm{E}$ & $40.151^{\circ} \mathrm{N}$ & Sines & $-8.876^{\circ} \mathrm{E}$ & $37.951^{\circ} \mathrm{N}$ \\
\hline Funchal & $-16.913^{\circ} \mathrm{E}$ & $32.644^{\circ} \mathrm{N}$ & Tavira & $-7.650^{\circ} \mathrm{E}$ & $37.126^{\circ} \mathrm{N}$ \\
\hline Gibraltar & $-5.353^{\circ} \mathrm{E}$ & $36.145^{\circ} \mathrm{N}$ & Terreiro do Paço & $-9.137^{\circ} \mathrm{E}$ & $38.708^{\circ} \mathrm{N}$ \\
\hline Girão Cape & $-17.006^{\circ} \mathrm{E}$ & $32.657^{\circ} \mathrm{N}$ & Tróia & $-8.859^{\circ} \mathrm{E}$ & $38.454^{\circ} \mathrm{N}$ \\
\hline Guincho Beach & $-9.474^{\circ} \mathrm{E}$ & $38.730^{\circ} \mathrm{N}$ & Valedelagrana & $-6.226^{\circ} \mathrm{E}$ & $36.578^{\circ} \mathrm{N}$ \\
\hline Kinsale & $-8.513^{\circ} \mathrm{E}$ & $51.695^{\circ} \mathrm{N}$ & Várzea São Brás and S. Lourenço & $-7.226^{\circ} \mathrm{E}$ & $38.859^{\circ} \mathrm{N}$ \\
\hline Horta (Faial Island) & $-28.624^{\circ} \mathrm{E}$ & $38.532^{\circ} \mathrm{N}$ & Viana do Castelo & $-8.830^{\circ} \mathrm{E}$ & $41.695^{\circ} \mathrm{N}$ \\
\hline La Coruna & $-8.395^{\circ} \mathrm{E}$ & $43.371^{\circ} \mathrm{N}$ & Vigário Beach & $-16.980^{\circ} \mathrm{E}$ & $32.649^{\circ} \mathrm{N}$ \\
\hline Lagoa & $-8.453^{\circ} \mathrm{E}$ & $37.135^{\circ} \mathrm{N}$ & Vila Franca de Xira & $-8.990^{\circ} \mathrm{E}$ & $38.954^{\circ} \mathrm{N}$ \\
\hline
\end{tabular}

that intensified (Codex 9857). Resende (1554) stated that "water rose with no wind", emphasizing the fact that the weather conditions associated with a tempest were missing. Most of the observations concerning water disturbance come from inside the estuary: Couto (1778) describes the sea agitation close to Lisbon downtown: "[...] in the sea the tempest was so great that destroyed and broke all ships staying in Lisbon harbor, some say that the Tagus river opened by its middle splitting its waters into a pathway and showing the sand bed". Also Osório (1919) describes “[...] the ships, sailors said, seemed to go in the sky; and (then) against the rocks; and the river open by its middle and close again" (Osório, 1919). The Codex 8009 from the Portuguese National Library quotes: "[...] Tagus with its violent tide fluxes and the furious agitation of the waves, rose in such a way that it submerged many ships, one claims that it opened in the middle of its waters, showing the sand of its bottom [...]".
An undated manuscript founded inside a copy of the 1495 Portuguese version of De Vita Cristi (that was supposed to be the first printed book in Portugal) describes: "[...] caravels at sea, fishing at 40 fathom depth, found themselves in dry land". "[...] an awful earth quake with much roar from the sea, and rivers, which came out of their reach, so that, the Tagus, that divided into several branches, some islets, which we call lezirias [...]" (Oliveira, no date). Upriver, in Vila-Franca-de-Xira, the description is: "[...] some sailors say [...] in this same river they saw the sky opening and it seemed like a burning oven and they saw coming out of it a large thunder with a large flame: and it was close to Vila Franca (Osório, 1919)". Perrey (1847) describes the following: "The sea awfully inflated swallowed a number of vessels. Tagus water, violently pushed by sea flood, spread above the margins and showed the dry riverbed"; however, he gives no specific source for the information. 
Beside the above descriptions, extra information can be obtained from the Inquiry conducted by the Marquis of Pombal. The priest of Várzea São Brás and S. Lourenço, from Elvas municipality "[...] In the same year, the 26th of the same month, another earthquake happened in Lisbon, and it was felt in a distance larger than sixty leagues [...] and many ship submerged in the sea" (Sousa, vol. II, p. 370, 1919). The priest from Benavente also comments: "[...] Also in the time of King D. Manuel, [...] there was one so big that one saw river Tagus rising so high that it poured and overflowed both streams" (idem).

\subsection{The 27 December 1722 Tavira tsunami}

On 27 December 1722 an earthquake stroke Tavira (Algarve) at approximately 5-6 p.m. It was felt all over Algarve, from San Vincent Cape up to the Spanish border (Mendonça, 1758). This information is reproduced in most seismic catalogs (e.g. Rodriguez, 1932; Runa and Freire, 1991; Martins and Victor, 2001). The flooding of Tavira area is well documented and persisted in the collective memory of the population. According to the "Chronica Serafica da Santa Provincia dos Algarves" (Belém, cap. XXII, 200-201, 1750) some days after, a thanksgiving procession took place in the town of Tavira, which was repeated every year since, in the same day of 27 December, with the presence of the Senate, the Communities and a large amount of people, "to keep the memory of the great benefit, although the large damage suffered, the entire town could have been entirely submerged" (Belém, 1750).

Using numerical tsunami modeling and multi-channel seismic processing, Baptista et al. (2007) estimated that the source of the 1722 Tavira earthquake had a magnitude circa $M_{w}=6.5$, and an epicenter close to $-7.82^{\circ} \mathrm{E}, 37.02^{\circ} \mathrm{N}$, in the submarine area close to the Algarve shore.

\subsection{The 1 November 1755 transatlantic tsunami}

There are several compilations of historical documents concerning the 1 November 1755 tsunami and earthquake (e.g. Solares et al., 1979; Levret, 1991; Baptista et al., 1998a, b; Solares and Arroyo, 2004). It devastated the Iberian and north Morocco coasts, causing great damage and casualties. It was observed all over North Atlantic coasts and in central and south America. The magnitude of the earthquake was recently re-evaluated from the macroseismic field as $M_{w}=8.5 \pm 0.3$ (Solares and Arroyo, 2004).

Reports describe $10-15 \mathrm{~m}$ waves at Cape St. Vincent and along the Gulf of Cadiz. In Lisbon the number of casualties, due exclusively to the tsunami, is estimated as close to 900 and the run in, in Lisbon downtown, is estimated as $250 \mathrm{~m}$ (Baptista, 1998a). The effects of the tsunami are described in Madeira, Cadiz and Cornwall, and agitation of closed waters was observed in faraway places like Scotland and Switzerland (see Chambers, 1757; Bewick, 1757; Borlase, 1755; Mendonça, 1758, and Trembley, 1755, published in 1757).

Lisbon: The water in the Tagus Estuary rose several times, and in a few minutes made three fluxes and refluxes rising above the highest spring tides two spans or fifteen English feet $[\ldots]$ when the high tide had run up three parts of it (Sachetti, 1756, published in 1757). "[...] the sea retreated, showing its bottom along the margins never seen before" (Mendonça, 1758). According to an anonymous letter dated the 18 November 1755 (Nozes, 157-189, 1990) "[...] suddenly I heard a great uproar: "the sea is rising" $[\ldots]$ suddenly an enormous water mass appeared at a close distance rising like a mountain [...]". Three years later, Mendonça (1758) describes: "[...] all of a sudden the sea entered the bar with a furious inundation $[\ldots]$ however crossing the previous limits, overtopped many buildings and inundated São Paulo quarter [... ]". Silva (1756) describes " [...] it flooded in some places with its flux and reflux [...] the Custom House, the Terreiro and the Vedoria [...]". These (and similar) descriptions allow to conclude that the water invaded Lisbon downtown in approximately $250 \mathrm{~m}$, being contained partially by the old city wall built by King D. Fernando.

Setubal: The Gentleman's Magazine of 1755 quotes a letter dated 4 December from Utrecht where we can read: "[...] Letters by the last post advice that no traces are left of St Ubes [Setubal], the repeated shocks and the vast surf of the sea having jointly concurred to swallow it up. It could the less withstand them, as it was situate at the head of a little gulf formed by the tide at the mouth of the [Sado] ..." (Urban, 1755). The Sea destroyed the city walls entering the city almost a quarter of a mile, carrying the boats to the streets (in Sousa, 1919). The sea carried 2 boats for more than 50 steps ( $\sim 45 \mathrm{~m}$ ) in land (Mendonça, 1758).

Porto: (or Oporto) is the second Portuguese town after Lisbon, located close to the Douro embankment in northern Portugal. The 1755 tsunami is described here in the following way: "The river which rose and fell surprisingly every quarter of an hour, for upwards of four hours at least, four or five feet, and sometimes more (Ellicot, 1757). In the Gentlemen's magazine we can read: "[...] The effect it had on the river was amazing; the tide rose considerably higher than was ever known except in case of flood; and the flux and reflux was so sudden, that in a minute or two it rose and fell five or six feet and continued for two or three hours. "[...] It ran up at the first with so much violence that it broke a Dutchman's hawser. Two of our Brazil fleet were going out, and had got to the bar, but the sea was so violently affected, that it forced them in again; they ran foul of each other, and were greatly damaged. The agitation was so great in the sea about a league beyond the bar, that, 'tis imagined the air got vent there"[...] (Urban, 1755). 
Figueira da Foz: "[...] however the biggest new was on the sea $[\ldots]$ by 10 o'clock and a quarter of the day, it started rising such water mounts [...] growing above the natural order 44 palms, more or less [...] for 3 or 4 times [...] uncovering rocks and sand never seen before [...]" (Arquivos do Ministério do Reino, 1756).

Algarve: "[...] The Sea of that coast raised so many poles (one pole $\sim 2.10 \mathrm{~m}$ ) above its ordinary surface, that it flooded many fields, and when retreating destroyed some fortresses, and all the town of Albufeira, leaving a large amount of fish on the bushes [...]" (Gazeta de Lisboa, 1755; Mendonça, 1758). Almost one century afterwards Lopes (1841) describes: "[...] By 9 and $1 / 2$ in the morning [...] a great thunder was heard and 3 or 4 minutes after the land shook with violence; the sea retreated partially more than 20 fathom leaving the beach dry; and immediately rushing over the land with such an impetus that it entered more than one league, overtopping the higher rocks; retreating and breaching three times in a few minutes, dragging in the flux and reflux enormous masses of cliffs and buildings, thus destroying almost all maritime villages".

Lagos: Following MDJF (1756) "[...] the sea entered onshore 7 poles high: the very strong city walls suffered with this misfortune [...]". An eyewitness report in Rocha (1991; in Costa et al., 2005) says: "[...] an awful earthquake with alteration in the sea, that in a few minutes ruined the city [...] the sea rising up till 13 and half palms high $[\ldots]$.

Albufeira: "[...] it was the defeat; those that escaped the earthquake could not escape from the sea" (MDJF, 1756). The priest reports in "Memórias Paroquiais"(IANTT, 1758) [...] the sea out of its limits entered the city and took all the quartier of Saint Ana, that included 7 streets, and many more houses, without leaving, in its flux and reflux any sign of the houses and made many casualties [...]. The newspaper Gazeta de Lisboa (1755), reports: "[... ]when the sea retreated took the fortress [...] and the whole city of Albufeira $[\ldots]$ leaving lots of fish in fields [...].

Faro: The city of Faro, separated from the sea by a barrier island, was protected against tsunami effects, according to the report of Castro (1786): "[...] Faro had the fortune that its river was on low tide $[\ldots]$. We could see the rising of the waves at the coast in such height that each one (all together) mounted the island without splitting itself. Entering the river $[\ldots]$ distributed in an number of foam waves[... ]in the city they cause minor impression, where the waters did not exceed the limits of a great tide [...]" (Castro, 1786). "[...] suffered the same calamity, submerging half of the place with all their houses never seen afterwards [...] (MDJF, 1756).

Monte Gordo - Tavira: "[...] The waves took all the huts from Monte Gordo beach, where there was commerce of fisheries, till the Conceição de Tavira, and destroyed all the islands (barrier islands) on the shore till Quarteira [...] (Relaçam, 1756; in Costa et al., 2005).

Castro Marim: "[...] the sea incursion made remarkable damage [...]" (MDJF, 1756).
Lagoa: The newspaper Gazeta de Lisboa (1755) describes: "[...] the sea on this coast raised many poles above its surface, entering the margins and inundating the fields; and when retreating, took with it the existing Fortresses".

Madeira: "[...] November the 1st, 1755, in the city of Funchal, on the Island of Madeira, at half an hour past nine o'clock in the morning, was perceived the shock of an earthquake [...] About an hour and a half after the shock had ceased, the sea, which was calm (it being a fine day, and no wind stirring) was observed to retire suddenly some paces, and, arising with a great swell, without the least noise, as suddenly advancing, overflowed the shore, and entered into the city. It arose full fifteen feet perpendicular above high water mark [... ]" (Heberden, 1755 letter published in 1757). $[\ldots]$ the sea all on a sudden rises as though it were the main body of it [...] November 3. Thank God we have no return of the earthquake, nor was the rising of the sea attended with any bad consequences in our part of the Island; though we hear, that at Machico and Porto da Cruz it did considerable damage $[\ldots]$ and when the sea recoiled, it was so far from its usual limits, as to discover the foundation of rocks, that never had been seen and which lay as far distant from the shore as our islet [...] the distance referred from the shore to the islet, something more than 200 yards (Chambers, 1755).

Porto Santo: "[...] on the 1st November 1755, we felt in this island the shock of a violent earthquake [...] the sea come out of its ordinary limits, about 10 o'clock, in the morning, running in a quarter mile [...] to a place called Estanco Velho. In spite of the fact that this is not a coeval source the results are coherent with the reports of Madeira Island (Anais de Porto Santo, in Sousa, 1919).

\subsection{The 16 November 1755 La Coruna tsunami}

According to Mendonça (1758) "[...] On the 16 November, about half past three there was a big explosion. It was felt in Santiago de Compostella and Coruña, where it caused some damage as well as flux and reflux of the sea [...]". The catalog of Rodriguez (1932) reports this event quoting Mendonça (1758). Perrey (1847) includes the following description: "The $16^{\text {th }}, 3$ hours 30 minutes in the afternoon, at Lisbon, the land subsided, and made the same effect as a trying ship; the sea inflated in a prodigious way".

\subsection{The 29 March 1756 Lisbon tsunami}

Perrey (1847) describes: "The 29th, in the morning, at Lisbon, one violent shock; the water of Tagus raised noticeably"; this author quotes the Journal Historique (1756) that reports the aftershock and the agitation in the waters of Tagus River, after several letters received from Lisbon. There is no description in Mendonça (1758) and the earthquake is not included in the catalogs of LNEC (1986), Martins and Victor (2001) or Sousa et al. (1992). Rodriguez (1932) included the same description in his catalog. 


\subsection{The 31 March 1761 North Atlantic tsunami}

Most of the original information concerning the 1761 earthquake and tsunami comes from the newspapers published in Lisbon (Gazeta de Lisboa) and London (The London Chronicle) and from the inquiry made at that time by the president of the Real y Supremo Consejo de Castilla (Royal and Supreme Council of Castilla) also bishop of Cartagena, Diego de Rojas y Contreras, who sent a letter to all local authorities asking information about 31 March 1761 earthquake, including reports of the earthquake occurrence, number of victims and damage (De La Torre, 1997). A series of letters published in the Philosophical Transactions of the Royal Society, reproduce and complete the basic descriptions. The first study of the 1761 earthquake and tsunami was published by Borlase (1762) in the Philosophical Transactions. Eighty five years later Perrey (1847) and ninety years later Mallet (1852) re-compiled all available data. These compilations were used in most of the modern studies (e.g. Moreira, 1984; De La Torre, 1997). All this information is compiled at Baptista et al. (2006).

About one hour and a quarter after the earthquake, a tsunami was observed in Lisbon (Baptista et al., 2006). Its amplitude is estimated as eight feet, affecting several ships that were left dry at some intervals (Molloy, 1761). Sea water changes were also observed along the Spanish coasts, namely Ayamonte, Puerto de Santa Maria, Cadiz and Barcelona but Baptista et al. (2006) didn't find quantitative details on arrival time or run-up. The tsunami was also observed very sensibly in Funchal and in Terceira (Azores). Good descriptions of the tsunami came from southern Ireland and UK, particularly Kinsale, where it was observed about six o'clock in the evening, Mounts bay (Cornwall), Penzance and Scilly Islands. There is also a reference for Barbados, where the tide ebbed and flowed, in about eight minutes, between eighteen inches and two feet, which was attributed to the 1761 tsunami.

Baptista et al. (2006) used backward ray tracing techniques to propose that the 1761.03.31 earthquake had its epicenter close to $-13^{\circ} \mathrm{E} 34.5^{\circ} \mathrm{N}$ and a magnitude close to 8.5.

A 1773 French document that was made available to us by Paul-Louis Blanc (personal communication) describing the effects of 12 April 1773 earthquake in Cadiz, that did not generate a tsunami in that Spanish town, refers indirectly to the 1761 event: "Hopefully the sea remained quiet, even if we feared that it came above itself, as [it happened] in the month of March 1761" (Journal Historique, 1773). This confirms the previous assumption on the approximate location of the source and on the regional character of the 1761 tsunami.

\subsection{The 18 December 1926 Lisbon tsunami}

On 18 December 1926, an earthquake occurred in Lisbon, at 2:45 p.m. The epicenter coordinates attributed by Martins and Victor (2001) are: $-9.20^{\circ} \mathrm{E}$ and $38.70^{\circ} \mathrm{N}$. There is at least one instrumental record in Coimbra, also used to locate the epicenter. The Lisbon newspaper Diário de Notícias (1926) reports "[...] Great agitation in the Tagus, it was felt in most boats that were leaned to the wall [...]. A curious report by several persons, that were using the Tagus ferries, is that the fishes were alarmed with the agitation of the sea and came to the surface in groups [...]. Groups of brave individuals approached the "Column Quay" to watch what was going on in the river [...]". This event shares some similarity with the 1531 Tagus event. Berninghausen (1964) reports the 1926 tsunami quoting the Seismological Dispatches of the University of Georgetwon. Cascais tide gauge station shows no clear tsunami waveform; the Seismological Dispatches of Georgetown university for this year report: " $[. .$. Lisbon, Portugal, Dec. 18 A violent earthquake lasting three seconds, today alarmed all Lisbon [...]" and for the next day: "[...] Lisbon, Portugal Dec. 19 - Lisbon has experienced a severe earthquake. The first shock Saturday lasted ten seconds. It was accompanied by subterraneous noise; the waters of the Tagus river rose considerably and soon the surface was covered with thousands of fish [...] (Tendorf, 1926).

\subsection{The 18 November 1929 Grande Banks tsunami}

On 18 November 1929, 20:32 UTC, a $M=7.2$ earthquake occurred at the southern edge of the Grand Banks triggering a large submarine slump with a volume estimated as $200 \mathrm{~km}^{3}$ (Fine et al., 2005) that moved along the Laurentian slope, rupturing 12 transatlantic cables and generating a tsunami that crossed the north Atlantic. The tsunami was recorded along the eastern seaboard as far south as South Carolina and across the Atlantic Ocean and in Portugal in Ponta Delgada and Leixões (close to Oporto). Recently Fine et al. (2005) include observations of tide records in Portugal for Lagos (south coast), Leixões (north coast) and Azores. This event is one of very few slide-generated teletsunamis (Fine et al., 2005) and the maximum amplitude in the Portuguese mainland coasts was observed at Leixões where it reach amplitudes close to $0.19 \mathrm{~m}$. In Ponta Delgada (Azores) the maximum observed amplitude was $0.14 \mathrm{~m}$.

\subsection{The 4 March 1930 Câmara de Lobos (Madeira) Rock Fall}

An enormous wave, caused by a massive rock fall close to Girão Cape in Madeira (cf. Fig. 1), entered the Vigario Beach 200-300 $\mathrm{m}$ in land (Freitas, 1989). The wave caused about 20 casualties, most of them women surrounded by their children, who were washing their laundry in the Vigario stream close to the sea. During the water reflux it was possible to see women and children carried out by the water and other debris (Rosa and Fernandes, 1930). Two other slides occurred in 1894 and in September 2004 at the archipelago of Madeira (Rodrigues, 2005), their effects on the coast need further investigation to be included in the catalog. 


\subsection{The 8 May 1939 North Atlantic tsunami}

An earthquake of magnitude $M_{s}=7.1$, occurred with epicentre $37.40^{\circ} \mathrm{N},-23.90^{\circ} \mathrm{E}$, Azores, (Buforn et al., 1988). A small tsunami was recorded at the tide stations of Ponta Delgada (S. Miguel) and Angra (Terceira Island). According to the local newspaper "Correio dos Açores" (1939) that quotes the information from the Azores Meteorological Service, the maximum peak to peak amplitude was $0.3 \mathrm{~m}$ at Ponta Delgada. The first shock occurred at 1:47 a.m. (GTM); three tsunami waves were recorded at Angra at 2:25, 2:29 and 2:45 a.m. The amplitude of Ponta Delgada tide station $(0.30 \mathrm{~m})$ is taken from Moreira (1968) because the original record is not available. We checked other tide gauge stations of the Portuguese network to conclude that this tsunami was not registered in mainland Portugal.

\subsection{The 25 November 1941 North Atlantic tsunami}

The earthquake occurred at 6:03 p.m. on 25 November 1941. The epicentre coordinates are $37.42^{\circ} \mathrm{N},-19.01^{\circ} \mathrm{E}$ and the magnitude 8.2 (Martins and Victor, 2001) and the surface wave magnitude is 8.4. A small tsunami was registered at the tide stations of Cascais, Lagos, Leixões, Douro (Portugal), Casablanca (Morocco), Pontinha (Madeira), Ponta Delgada (Azores), Newlin (Cornwall, UK), being the maximum amplitude observed $0.45 \mathrm{~m}$ (peak to peak) at Casablanca (Mogador) in Morocco.

The Portuguese newspapers report tsunami visual observations at Tagus estuary: "[...] the phenomenon was also felt in Tejo (Tagus), where the waters surge for several seconds. The ships anchored in the river oscillate; this fact caused some fear among the crews. In the docks the small ships crashed against each other without damage [...]"(Diário de Noticias, 1941a); At Douro estuary the sea overtopped the beaches to the streets: at Douro estuary the panic was not less, caused by the shock but also by the roaring of the sea that furiously overtopped the beaches and flood the streets, reaching St. Bartolomeu Street [... ]"; in Vila Franca de Xira: "[...] The men at the pier saw, with panic, great waves and the Tagus rebelled threatening the walls, at the same time the ships in the river oscillate like fragile "nut barks" [...]" Diário de Noticias (1941b).

The Gibraltar Chronicle, from 26 November 1941, reports (p. 2) that "World records big earthquake - Lisbon sways under shock" and says: "[... ] London, November 26, Probably the biggest earthquake tremor known, has just been recorded on the instruments of scientists all over the world [...] however can not agree as to the exact location [...] it must have occurred under the Atlantic Ocean. Some place it between the Azores and Madeira [...]" (Gibraltar Chronicle, 1941a) On November 27 the same newspaper refers: that yesterday's earthquake was under the Atlantic, $790 \mathrm{~km}$ offshore Portugal in line with the Azores Island of Sao Miguel" Gibraltar Chronicle (1941b).

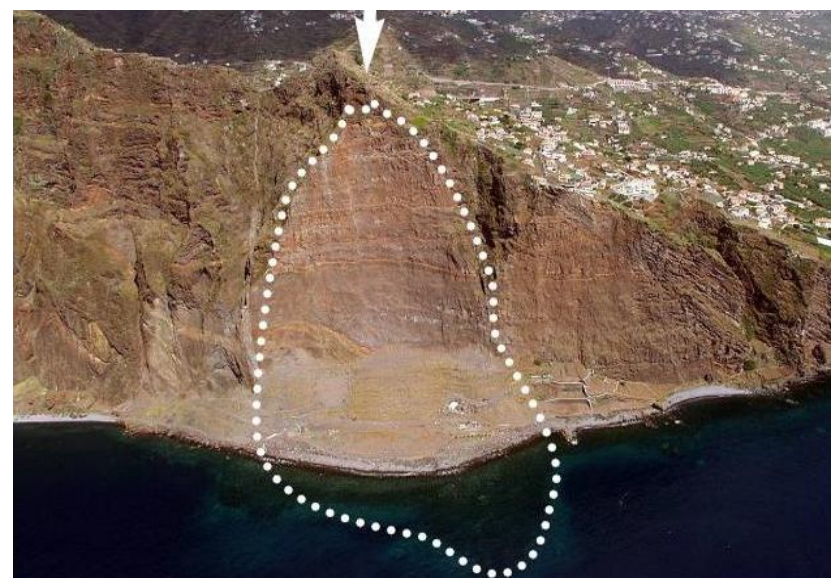

Fig. 1. Cape Girão: Recent Aerial photo showing the scar of the 1930 landlside.

\subsection{The 28 February 1969 Horseshoe tsunami}

An $M_{S}=7.9$ earthquake occurred the 28 February 1969, at $2 \mathrm{~h} 40 \mathrm{~min}$ (TUC) on the SW Iberia margin. Its epicentre was located at $-10.57^{\circ} \mathrm{E}, 36.01^{\circ} \mathrm{N}$, and its estimated focal depth was $22 \mathrm{~km}$ (Fukao, 1973). It generated a small amplitude tsunami that was recorded in the tide gauges of mainland Portugal: Cascais, Lagos, Faro; along Tagus estuary close to Lisbon: Terreiro do Paço, Cacilhas, Cabo Ruivo; in the Azores Islands: Horta (Faial Island); in Morocco: Casablanca; Spain: Cadiz and in Canaries Islands. The maximum amplitude observed was $0.6 \mathrm{~m}$ at Casablanca. This event is discussed in detail in Baptista et al. (1992), Heinrich (1994) and Gjevik et al. (1997).

Most of the information available regards tide gauge records but in the harbor of Matosinhos the fishermen offshore, close to the coast, felt a sudden and strong agitation in the sea, but they were unable to evaluate what happen in the coast (in Diário da Manhã, 29 March 1969).

There is some information concerning seaquake observations (Ambraseys, 1985). The ship "Manuel Alfredo" that was $240 \mathrm{~km}$ offshore Sines, was suddenly surprised by a strong noise and the crew thought that the ship ran into rocks, then the crew realized it was not possible due to the location of the ship. The crew observed that the water, in the sea, looked as it was boiling. Some minutes later they knew through a Moroccan radio that an earthquake happened. The passengers that were asleep, in their cabins, did not panic and stayed quiet. A 32000 -tone ship located close to the Horseshoe Abyssal Plain suffered serious structural damage and was obliged to return to Lisbon, where it was dry-docked and surveyed (Ambraseys, 1985). 


\subsection{The 17 July 1969 tsunami}

Moreira (1968) gathered a group of three mareograms from the tide stations of Santa Cruz de Tenerife (Canary Islands), Angra (Terceira Island), Lagos and Cascais, where a clear tsunami signal can be observed. The maximum peak-to-peak amplitude observed on the Portuguese coast is $0.06 \mathrm{~m}$ at Lagos. There is no significant earthquake that we can correlate with this event and so we consider it source as "unknown".

\subsection{The 26 May 1975 Gloria Fault tsunami}

The 26 May 1975 earthquake, of magnitude $M_{s}=7.9$, occurred in the North Atlantic close to the Azores archipelago. Its epicentre, as given by USGS, was $-17.5^{\circ} \mathrm{E}, 35.9^{\circ} \mathrm{N}$, $200 \mathrm{~km}$ south of the Gloria Fault. The tsunami wave was recorded in a set of coastal tide gauges where amplitudes range up to $30 \mathrm{~cm}$ in Lagos (see Fig. 2 for locations). Kaabouben et al. (2008) presented recently an analysis of the tsunami data to analyse the earthquake focal mechanism.

According to Diário dos Açores (1975a, b): "About 8:15 a.m. (local time) three seismic station of the archipelago recorded an earthquake [...] with epicentre $-16^{\circ} \mathrm{E}, 37^{\circ} \mathrm{N}$, that is $840 \mathrm{~km}$ the East-Southeast of S. Miguel. About 9:40 a.m. (local time), at the artificial harbour and in the "old sardine pier" it was observed a fast withdraw of the sea, returning just after, reaching the high tide mark. In those places, fertile areas of the bottom remained uncover, and some boats touched the bottom". "[...] In Ponta Delgada and Horta it was observed a tsunami, caused by the earthquake and the tide gauge (in Horta) recorded an oscillation with maximum amplitude of $34.5 \mathrm{~cm}$ ". In Portugal mainland, the maximum observed amplitude was $30.0 \mathrm{~cm}$ at Lagos tide gauge.

\subsection{The 1 January 1980 Azores tsunami}

On 1 January 1980 an earthquake occurred between Terceira and S Jorge islands at 16:42:40 (Azores). The hypocentral coordinates for this shock were (NEIC) $38.81^{\circ} \mathrm{N},-27.78^{\circ} \mathrm{E}$, $H=10 \mathrm{~km}$, the magnitude is $M_{s}=6.7, M_{w}=6.8$ (Hirn et al., 1980; Borges et al., 2007). This strike slip event generated a small amplitude tsunami recorded at Angra (Terceira Island) and the maximum amplitude observed was $0.3 \mathrm{~m}$ peak to peak. The following tide records were checked to confirm the tsunami in Portugal mainland: Aveiro, Viana do Castelo, Faro, Sines; no tsunami signal was found.

\section{Pre-historical events}

To expand the time span of the tsunami catalog to pre-historic times the most important information available regards paleotsunami studies based on the identification of high energy deposits on the sedimentary record. The observation of recent events shows that water run-up and swash transport ma- terials landwards from the sea bottom, forming at some distance inland sand sheets and washover fans with variable textures and grain sizes, sometimes including cobbles, boulders or even large blocks. Textural variations, sediment content, micro and macrofauna, landward variations in thickness and height can be used as markers of tsunami deposits (see Luque et al., 2002 and references herein). A number of studies have been conducted in the southwestern coasts of Portugal and Spain (e.g. Andrade, 1992; Dawson et al., 1995; Luque et al., 2001; Ruiz et al., 2005) contributing for the identification of a series of possible events that probably struck the Portuguese coasts during and before Roman times.

\subsection{The 6.0-7.0 kyr BP paleotsunami}

The oldest claimed Holocene tsunami deposit around Cadiz Gulf was identified by Scheffers and Kelletat (2005) near the Guincho Beach, NW Lisbon. It corresponds to a series of giant boulders and cobbles, located $14 \mathrm{~m}$ above mean sea level, where radiocarbon dating is $6000-7000 \mathrm{yr}$ BP (Scheffers and Kelletat, 2005). Similar records were not found on the southwestern coast of Spain, but sea level height, close to its Holocene maximum, generated flooding in estuaries during this period (Dabrio et al., 2000) that could prevent the identification.

\subsection{The 5.3-5.5 kyr BP paleotsunami}

A later event was identified by Vizcaino et al. (2006), using a turbidite paleoseismological approach based on the synchronicity between mass wasting deposits filling distant basins. Radiocarbon dating of an important debris flow on a core made offshore, close to Marques de Pombal fault, concluded for an age of $5488 \pm 98 \mathrm{yr}$ BP. Ruiz et al. (2005) also claimed to have identified a high energy event approximately dated $5309 \mathrm{yr}$ BP which caused the breakthrough of the Doñana spit. If we consider both independent identifications as the signature of the same event, we can attribute it an age of 5.3-5.5 kyr BP.

\subsection{The 4.2 kyr BP paleotsunami}

Ruiz et al. (2005) based on the paleogeographic evolution of Doñana National Park claimed the existence of a high energy event in $4153 \mathrm{yr}$ BP.

\subsection{The 3.6 kyr BP paleotsunami}

The only positive identification of a high energy event for the epoch 3.6 kyr BP was made by Vizcaino et al. (2006) based on a debris flow found in the already described Marques de Pombal core. They attribute it a radiocarbon age of $3552 \pm 35 \mathrm{yr}$ BP. Having no other positive identification from coastal tsunami deposits we cannot discard the possibility of a large earthquake that did not generate a significant tsunami, 


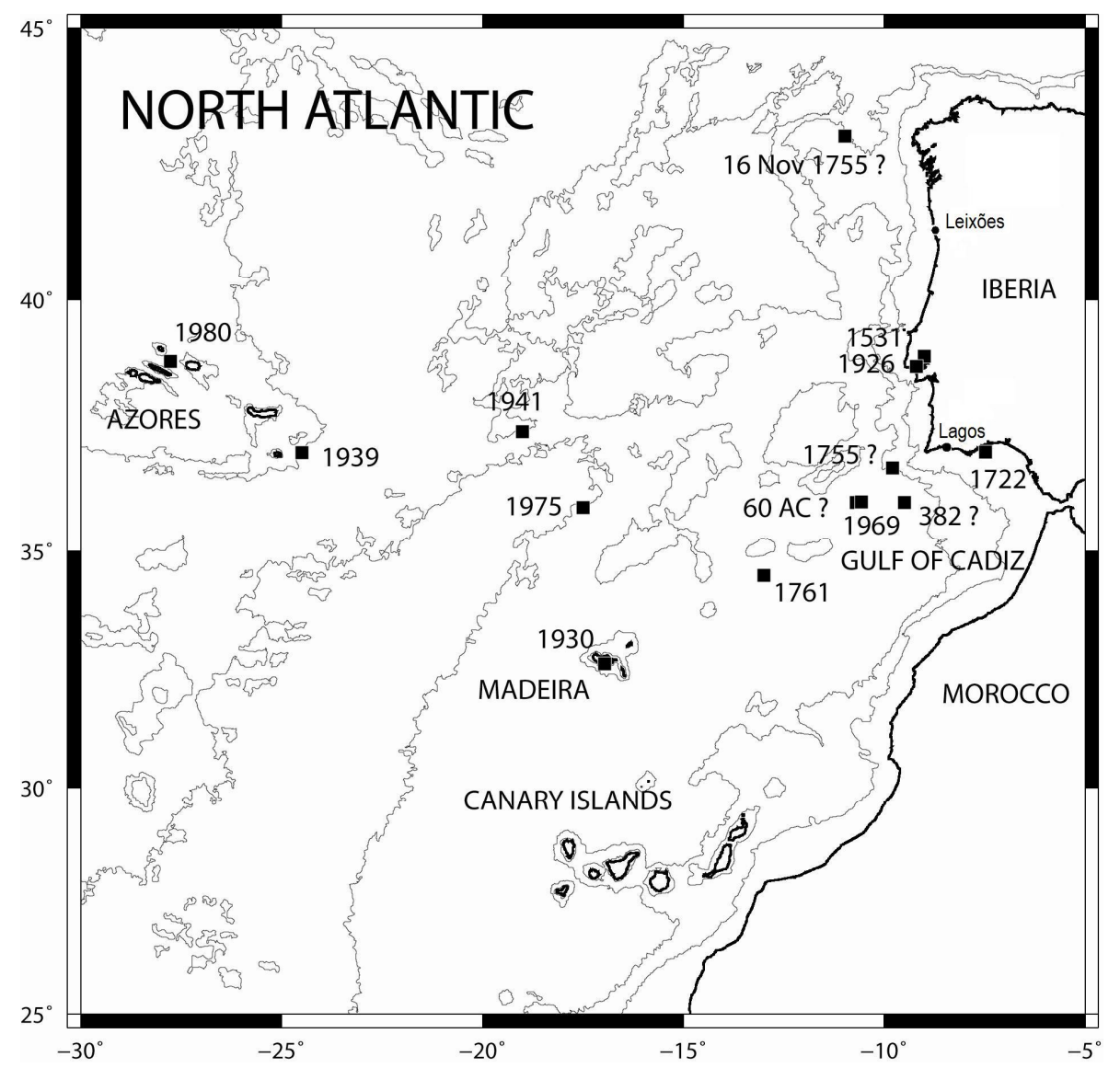

Fig. 2. Location of the presumed source for most of the events included in Table 2. We include in the figure the events of 1939 and 1980 generated in the Azores but with no significant impact on the mainland Portuguese coasts.

while producing an important debris flow on the SW Portuguese coast. Ruiz et al. (2005) identified two other high energy events in $3862 \mathrm{yr} \mathrm{BP}$ and $3763 \mathrm{yr} \mathrm{BP}$, which could be interpreted as a single tsunami layer (Ruiz et al., 2007).

\subsection{The 2.4-2.7 kyr BP paleotsunami}

Lario (1996) identified a large erosional episode between 2700 and $2400 \mathrm{yr}$ BP in Punta Umbria that changed the drainage system and attributed it to a high energy event.

\subsection{The 2.2-2.3 kyr BP paleotsunami}

A high energy event 2200-2300 yr BP was positively identified by Luque et al. (2002) on the Valedelagrana Spit Bar (Bay of Cadiz, Spain), with the input of coarse sands into tidal marsh deposits, similar to the sedimentary signature of the 1755 event in the same place. Vizcaino et al. (2006) found a similar result for a debris flow in the Marques de Pombal core, attributing it a radiocarbon age of $2293 \pm 35 \mathrm{yr}$ BP. Luque et al. (2001) consider that the sedimentary sig- nature found in Cadiz Bay corresponds to the impact of a tsunami similar to 1 November 1755 and also that it matches the tsunami occurring in roman times in $218 \mathrm{BC}$, included in the Rodriguez (1932) tsunami catalog.

\section{The Tsunami catalog}

\subsection{Structure of the catalog}

We present in Table 2 a synopsis of all events included in the Portuguese tsunami catalog. The fields considered there characterize the source (location, date and time, sub-region), the cause classified as Earthquake (submarine earthquake, $\mathrm{ER}$, earthquake associated, EA, earthquake landslide, EL, earthquake marine slide, ES), Volcano (submarine eruption, VO, volcano associated, VA, volcanic landslide, VL, volcanic marine slide, VS) or Slump (gravitative landslide, GL, gravitative marine slide, GS, gravitational snow avalanche, GA, glacier calving, GC), the reliability (states the uncertainty on the occurrence of each event), and the tsunami size (intensity, run up height, and amplitude). 
Table 2. Date - date of the event; Time - time of the event; Reliability - reliability of the event; Cause: ER (Earthquake); RF (Rock Fall) or LS (Landslide). The time attributed to the 17 July 1969 tsunami is approximate. Sub-regions of Atlantic (AT) region are coded as: SWIT Southwest Iberian Transpressive zone; TE - Tagus Estuary; GFD - Gloria Fault Domain; GB - Grand Banks; MAD - Madeira. Lat and Lon - Latitude and Longitude in degrees; $H$ - focal depth in km; TI - tsunami intensity; $K$ - tsunami intensity; $R$ - run-up height in (m); $A$ Max Amplitude - maximum amplitude observed in the Portuguese tide gauge network (m); in all case Un means "unknown".

\begin{tabular}{|c|c|c|c|c|c|c|c|c|c|c|c|}
\hline \multirow[t]{2}{*}{ Date } & \multirow[t]{2}{*}{$\begin{array}{l}\text { Time } \\
\text { hh mm ss }\end{array}$} & \multirow[t]{2}{*}{$\begin{array}{l}\text { Relia- } \\
\text { bility }\end{array}$} & \multirow[t]{2}{*}{ Cause } & \multirow[t]{2}{*}{$\begin{array}{l}\text { Sub- } \\
\text { region }\end{array}$} & \multicolumn{3}{|c|}{$\begin{array}{l}\text { Source } \\
\text { location }\end{array}$} & \multirow{2}{*}{$\begin{array}{l}\text { TI } \\
\text { Sieberg } \\
\text { Ambraseys }\end{array}$} & \multirow{2}{*}{$\begin{array}{l}K- \\
\text { Imamura } \\
\text { Papadopoulos }\end{array}$} & \multirow{2}{*}{$\begin{array}{l}R- \\
\text { Run-up } \\
(\mathrm{m})\end{array}$} & \multirow{2}{*}{$\begin{array}{l}A-\text { Max } \\
\text { Amplitude } \\
(\mathrm{m})\end{array}$} \\
\hline & & & & & $\begin{array}{l}\text { N Lati- } \\
\text { tude }\end{array}$ & $\begin{array}{l}\text { E Longi- } \\
\text { tude }\end{array}$ & $\begin{array}{l}H- \\
\text { depth } \\
(\mathrm{km})\end{array}$ & & & & \\
\hline $60 \mathrm{BC}$ & Un & 3 & ER & SWIT & 36.00 & -10.70 & - & 4 & VII & - & - \\
\hline $382 \mathrm{AD}$ & Un & 3 & ER & SWIT & 36.00 & -09.50 & - & 4 & VI & - & - \\
\hline 26 Jan 1531 & 04:30:00 & 4 & ER & $\mathrm{TE}$ & 38.90 & -09.00 & - & 4 & VII & - & - \\
\hline 27 Dec 1722 & 17:30:00 & 4 & ER & SWIT & 37.02 & -07.48 & - & 3 & VI & - & - \\
\hline 26 Dec 1746 & - & 0 & - & - & - & - & - & - & - & - & - \\
\hline 28 Apr 1752 & - & 0 & - & - & - & - & - & - & - & - & - \\
\hline 1 Nov 1755 & 09:40:00 & 4 & ER & SWIT & 36.70 & -09.80 & - & 6 & XI & $>10$ & - \\
\hline 2 Nov 1755 & - & 0 & - & - & - & - & - & - & - & - & - \\
\hline 16 Nov 1755 & $15: 30: 00$ & 2 & ER & SWIT & 43.40 & -11.00 & - & 2 & III & - & - \\
\hline 21 Dec 1755 & - & 0 & - & - & - & - & - & - & - & - & - \\
\hline 31 Jan 1756 & - & 0 & - & - & - & - & - & - & - & - & - \\
\hline 29 Mar 1756 & Un & 2 & ER & $\mathrm{TE}$ & 38.70 & -9.20 & - & 2 & III & - & - \\
\hline 31 Mar 1761 & 12:01:00 & 4 & ER & GFD & 34.50 & -13.00 & - & 3 & VI & 2.4 & - \\
\hline 4 Jul 1809 & - & 0 & - & - & - & - & - & - & - & - & - \\
\hline 18 Dec 1926 & $14: 45: 00$ & 4 & $\mathrm{ES}$ & $\mathrm{TE}$ & 38.70 & -9.20 & - & 2 & IV & - & - \\
\hline 18 Nov 1929 & $20: 32: 00$ & 4 & $\mathrm{ES}$ & GB & 44.50 & -56.30 & - & 1 & II & - & 0.19 (Leixões) \\
\hline 4 Mar 1930 & 18:03:00 & 4 & GL & MAD & 32.65 & -16.97 & - & 4 & VIII & $>5$ & - \\
\hline 25 Nov 1941 & 18:04:00 & 4 & ER & GFD & 37.42 & -19.01 & 25 & 1 & II & - & 0.10 (Lagos) \\
\hline 28 Feb 1969 & $02: 40: 32$ & 4 & ER & SWIT & 36.01 & -10.57 & 22 & 2 & III & - & 0.30 \\
\hline 17 Jul 1969 & 05:00:00 & 4 & Un & Un & Un & Un & - & 1 & II & - & 0.13 (Lagos) \\
\hline 26 May 1975 & 09:11:51 & 4 & ER & GFD & 35.90 & -17.50 & 15 & 1 & II & - & 0.30 (Lagos) \\
\hline
\end{tabular}

The source location of non-instrumental events is rather uncertain, except if macroseismic data exist and the tsunami is inferred from the earthquake source area. If there is no additional information on tsunami propagation or run-up, epicenter coordinates (Table 2) are obtained from seismic catalogs. In our case most events were triggered by earthquakes and the corresponding epicentral parameters (longitude, latitude and depth) are used to estimate the location of the fault which movement is supposed to have deformed the seafloor and thus, generated the tsunami. The reliability is assessed with Iida 5 grade scale, where 0 means a "very improbable tsunami" and 4 a "definite tsunami". The last columns characterize the tsunami size: the tsunami intensity TI, the run up height $R$, and the amplitude $A$.

The intensity of the tsunami is described by both SiebergAmbraseys (Ambraseys, 1962) and Imamura-Papadopoulos (Papadopoulos, 2003) scales. The Tsunami Intensity in the Sieberg-Ambraseys ranges from 1, for a very small tsunami only detected by tide gauges, to 6 for a catastrophic tsunami, spreading devastation along coastal areas. The Tsunami Intensity scale by Imamura and Papadopoulos (2001) is arranged according to the effects on objects like boats, damage to buildings, and ranges from I to XII; the authors propose a tentative correlation with water height; the run-up height $R$, this is the maximum observed in the area affected by the tsunami; the amplitude, $A$, reveals the existence of the tide gauge data and the place and maximum amplitude observed is reported in the table. The intensity assigned to each event is based only upon the descriptions and reports in spite of the reliability attributed to the event. In the descriptions the Sieberg-Ambraseys' intensity is represented by TI while the Imamura-Papadopoulos' intensity is denoted by $K$ (Papadopoulos, 2003).

We did not compute tsunami magnitudes. This parameter defined by Murty and Loomis (1980) is related to the initial potential energy of the tsunami integrated all over the tsunami source area. It is only applicable to earthquake generated tsunamis and for those cases in which the source parameters are well established. In such cases it is possible to compute the solid earth displacement (see Tinti et al., 2004, for details). 


\subsection{Unreliable events}

The re-appraisal of the different data sources and the analysis of new ones, that was performed in this study, led us to discard some events, presented in the preliminary GITEC catalogue (Tinti et al., 1996), mainly because they have been included in previous catalogs of tsunamis in Iberia (e.g. Perrey, 1847; Mallet, 1952; Rodriguez, 1932; Berninghausen, 1964; Moreira, 1991; Campos, 1992). We discard the 26 December 1746, the 28 April 1752, the 2 November 1755, the 21 December 1755, the 31 January 1756 and the 4 July 1890 events.

The 26th December 1746 event: Berninghausen (1964) reports this event quoting Mallet (1852): “[...] the tide was very low (at the time of the shock) and it was observed that the sea, which had been quite calm, rose considerably [...]. The seismic catalog of Martins and Victor (2001) reports 2 earthquakes in 1746, with no specific day and/or month. The shocks are located at $-8.5^{\circ} \mathrm{E}, 40.3^{\circ} \mathrm{N}$, and $-7.9^{\circ} \mathrm{E}$, $38.2^{\circ} \mathrm{N}$, both with magnitude 3.0. Mendonça (1758) reports only one event for this year, in Lima (Peru). Moreira (1991) reports events in 1746 with no specific date, felt in Assumar, Pombal, Águeda, Espinhel, Alandroal. Some answers from question number ten of the Marques de Pombal Inquiry that are transcribed in Moreira (1991) and Runa and Freire (1991) refer to an earthquake ten years before 1756 , but no reference is made to a tsunami, as it would be expected as the above localities are inland, far away from the sea. Perrey (1847), Mallet (1852) and Rodriguez (1932) do not mention this event.

The 28 April 1752 event: This event is listed in Perrey (1847), Rodriguez (1932) and Berninghausen (1964). The description of Berninghausen (1964), quoting Mallet (1852), says: "[...] April 28. Portugal. A violent earthquake at Buarcos and Aveiro was accompanied by inundation". Mendonça (1758) refers only one event in this year (1752) but on 6 September, at Clermont and Rion (France). We checked the answers given to the Inquiry made by the Marquês de Pombal for Buarcos, Aveiro and Figueira da Foz. Several answers report an event on 23 August 1753. Moreira (1984) also excludes this event on the basis that it is neither reported by Gazeta de Lisboa nor by Mendonça (1758). The catalog of Martins and Victor (2001) includes 2 events in 1752 and none in 1753.

The 2 November 1755 event: The 2 November 1755 event is one among a large sequence of aftershocks of the 1755 earthquake, which stood until March 1756. On 2 November the day after the earthquake, a shock was felt and the sea was described as agitated (Rodriguez, 1932). All coeval sources report extensively the aftershocks but the exact date of this event is rather uncertain (Rodriguez, 1932). The epicentre coordinates are considered to be $37.00^{\circ} \mathrm{N}$ and $-10.50^{\circ} \mathrm{E}$ by the Martins and Victor (2001) catalog but the magnitude if this event is listed as $M_{b}=3$, incompatible with the generation of a tsunami. According to the on-line version of the Spanish Tsunami Catalog (Instituto Geografico
Nacional, 2005) water flux and reflux was also described in Gibraltar but a tsunami reliability of zero is attributed. Mendonça (1758) reports aftershocks during the following day, "in the 24 hours after the earthquake the earth continued shaking" but no tsunami is reported.

The 21 December 1755 event: A description of a tsunami the 21 December 1755 is included in Rodriguez (1932): "[...] At about 9 an earthquake occurred in Lisbon, with two shakings of short duration but so violent that caused damage and ruin in the city. The Tagus overflowed. 300 people died in the rubbles and drowned in the waters of this river [...] the realm of Algarve suffered a lot. At the coast the sea advanced one league. People at Spanish frontier suffered less [...]". Rodriguez (1932) quotes no original source for the information.

This event is not mentioned in any coeval sources of the Portuguese archives. Mendonça (1758) devotes the final part of his catalog to the aftershocks sequence of the 1755 earthquake and there is only one event with associated tsunami (the Coruña 16 November 1755 event): "[...] on the 21, by 9 o'clock (in the day) there was one that caused so violent concussions, that caused in Lisbon and surroundings some ruins. If it lasted more, there would certainly be more damage". (Mendonça, 1758, p. 62)

The 31 January 1756 Lisbon event: According to Rodriguez (1932) on 31 January 1756 a tidal wave flooded the coast and left some fish on the sand. However, this catalog is the only reference to such event: a contemporary source (Mendonça, 1758) reports: "[...] On January 1756 there were many earthquakes, that I cannot find any memories, and that I cannot remember, because I just noticed the greater ones on April the 25th (this year) and later on [...]". Perrey (1847) does not include any information on this event. In the absence of conclusive information from the earthquake itself, not included in the catalogs of LNEC (1986), Martins and Victor (2001) or Sousa et al. (1992), we conclude that Rodriguez (1932) description must not be taken into consideration.

The 4 July 1809 event: Berninghausen (1964), quoting Mallet (1852), reports a tsunami in Portugal on 4 July 1809. The description is: "[...] Portugal. No shock listed. An extraordinary flux and reflux of the sea is observed near Lisbon [...]". The Portuguese newspaper for this month Gazeta de Lisboa, July 1809, does not report any sea disturbance. In Rodriguez (1932), quoting Perrey (1847) there is only one event reported for Lisbon on 26 October the same year, but no reference to any sea disturbance. Mallet (1852) mentions a flux and reflux in Spezia near Genoa and says that the same phenomenon was observed in Lisbon. As there is no evidence of any Portuguese historical source, we shall not consider this event in the catalog.

The 2 February 1816 event: It is listed in Rodriguez (1932) earthquake catalog and is reported in the Lisbon newspaper Gazeta de Lisboa. The original source just mentions a "light shock" and no reference is made to a 
tsunami or any sea agitation, while Rodriguez (1932) refers a strong shock and states that a ship 270 leagues away from Lisbon felt the shock. We were not able to find any coeval source to support the evidence of this event and this entry which was previously considered as reliability 1 tsunami is now eliminated from the catalog, after a reanalysis of all available sources.

The 14 August 1978 event: While reported by Campos (1992) it was not recorded in any of the tide stations of Portugal mainland: Cascais, Lagos, Figueira da Foz, SetúbalTroia. This fact and the small magnitude of the event 4.9 (according to Carrilho et al., 2004) lead us to eliminate this entry of the Portuguese catalog. The signal was recorded in Cadiz (Campos, 1992) with amplitude $0.12 \mathrm{~m}$ peak to peak.

\subsection{Tsunamigenic source areas}

The events described above were generated in the complex plate boundary domain that extends between the Azores and western Mediterranean (cf. Fig. 2 for locations). The average mean velocity between the Nubian and the Eurasian plates as deduced from spatial geodesy (Fernandes et al., 2007) reaches only $5 \mathrm{~mm} / \mathrm{yr}$ close to the Iberian margin, creating a situation where very large earthquakes can only be generated every $2 \mathrm{kyr}$ in a single tectonic source. This order of magnitude is coherent with our present catalog and, in particular, the deductions from paleotsunami research.

We can consider five main potential tsunami source areas with specific tectonic styles and so, with different tsunamigenic mechanisms (see Fig. 3 for locations). The first corresponds to the Azores, the second to the Gloria Fault and neighboring interplate domain, the third one to the Southwest Iberian Transpressive (SWIT) domain, the fourth to the Alboran-Cadiz wedge (ACW) and the fifth to the Grand Banks area. Finally, we must also consider regions where local tsunamis have been generated: the Tavira off-shore, Girão Cape (in Madeira Island) and the Tagus Estuary.

The Azores are a transtensive domain that incorporates an active spreading axis between the Eurasian and Nubian plates. It is an area of active volcanism, where most of the earthquakes are extensional events or strike slips with low tsunamigenic potential. Two instrumental events were generated in the Azores domain (8 May 1939 and 1 January 1980) but they had only regional impact. The descriptions concerning the Azores tsunami of 26 July 1691 apparently show similar characteristics but there are no instrumental data available. From the descriptions and data included in this work we conclude that tsunamis generated in the Azores do not affect the Portuguese mainland.

The Gloria Fault Domain (GFD) corresponds to the plate boundary between $24^{\circ} \mathrm{W}$ and $19^{\circ} \mathrm{W}$. It is an area of scarce seismicity characterised by right strike slip motion (Buforn et al., 1988). In spite of this, several instrumental tsunami events have been identified (8 May 1939, 25 November 1941, 26 May 1975) and, according to Baptista et al. (2006) it is also the probable location of the 31 March 1761 tsunami source. These events not only follow the Gloria Fault itself but also a second source zone also striking almost EW, ca. $200 \mathrm{~km}$ south (Lynnes and Ruff, 1985). This can correspond to either the development of a tectonic block or the re-activation of a previous transform domain (Kaabouben et al., 2008). Tsunamigenic earthquakes generated along the Gloria Fault Domain are almost pure strike events, with moment magnitudes larger than 8 and average slip close than $10 \mathrm{~m}$. This type of seismic source is able to generate small tsunamis with amplitudes of some dozens of $\mathrm{cm}$, but in some cases, with significant effects on harbours.

The SW Iberian Transpressive (SWIT) domain is interpreted as a complex plate boundary, where most of the damaging earthquakes and tsunamis that affected the coasts of Portugal, Morocco and Spain, here including the 1 November 1755 mega-tsunami, were generated. Here we can identify four most important features which characteristics and level of activity have been studied by geophysical and tectonic methods, each of them corresponding to a long tectonic source able to generate a $M>8$ earthquake: the northern flank of the Gorringe Bank, the Horseshoe, the Marques de Pombal and the Portimão Bank faults. Most of the damaging tsunamis, here including 1 November 1755 and the paleotsunamis described in the text were generated here. The two large historical pre-1755 events (60 BC and $382 \mathrm{AD})$ were probably generated also in this area.

The Gorringe Bank is a large uplifted block of oceanic lithosphere approximately $180 \mathrm{~km}$ long and 60-70 km wide, trending N55E. It is a huge morphological high that reaches $25 \mathrm{~m}$ below sea level. This lithospheric block is usually interpreted as an almost continuous section of oceanic crust and upper mantle and is associated with a large isostatic anomaly (ca. $300 \mathrm{mGal}$ ) interpreted as a sign of the lack of isostatic equilibrium (Bergeron and Bonnin, 1991) and, thus, a potential seismogenic and tsunamigenic feature. However there is no historical or instrumental tsunami event which source can be conclusively located there.

The Horseshoe Fault (Gràcia et al., 2003; Zitellini et al., 2004) is a reverse fault oriented perpendicular to the present day kinematic displacement of Nubia with respect to Iberia. It is one of the most important tectonic accidents identified in the area but, while close to the source area of 28 February 1969 earthquake, the geometry of the fault does not match the structure as mapped by seismo-stratigraphy.

The Marques de Pombal Fault (Zitellini et al., 2001) is a large active compressive tectonic structure located $100 \mathrm{~km}$ offshore SW Cape St. Vincent. It displays a pronounced drag fold on the fault hanging-wall and the height of the escarpment is taller in the north where it reaches $1.2 \mathrm{~km}$. The northernmost segment is offset by a WNW-ESE wrench fault. Mass wasting deposits associated with the uplift are also visible, such as, debris flow deposits and ridges that correspond to turbidity levees (Gràcia et al, 2003; Terrinha et al., 2003). This is the most relevant active structure mapped 


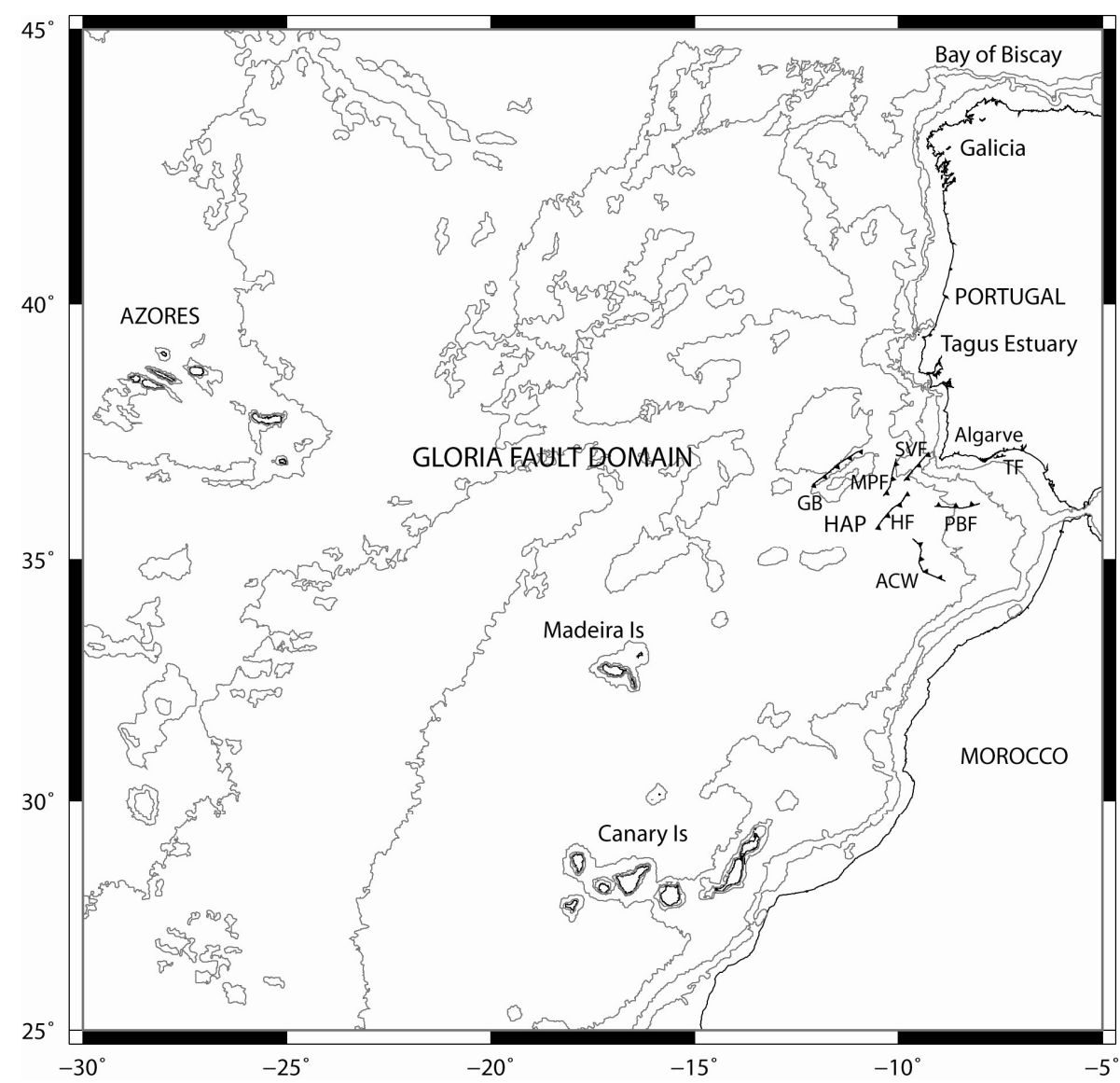

Fig. 3. Sketch of the main tsunamigenic zones for Portugal. Main active geological features described in the text are labeled as follows: SVF - St. Vincent Fault; TF - Tavira Fault; MPF Marques de Pombal Fault; GB - Gorringe Bank; HF - Horseshoe Fault; PBF - Portimão Bank Fault; ACW - Alboran-Cadiz Wedge; HAP Horseshoe Abyssal Plain. Grand Banks area is outside the picture.

in the SW Iberian area and was proposed as the source of the 1755 event. However, its length as deduced from multichannel seismic data is too small to account for the known earthquake and tsunami magnitude.

The Portimão Bank Fault (PBF) was recently mapped by the NEAREST team (Terrinha et al., personal communication) along the southern flank of the Portimão Bank.

The Alboran-Cadiz wedge was considered by Gutscher et al. (2006) as a potential seismogenic and tsunamigenic feature. This interpretation was mainly based on thermomechanical modeling, and on the estimated relative velocity vis-à-vis the surrounding lithosphere, which was considered as twice the relative motion between Nubia and Eurasia, i.e. close to $1 \mathrm{~cm} / \mathrm{yr}$. There are no large instrumental events that can be attributed to this source area. However, since previous attempts to model the whole 1755 tsunami and earthquake observations with a single source within SWIT were not completely successful, we must include $\mathrm{ACW}$ as a potential source. The positive identification of large magnitude pre-historic events around the Gulf of Cadiz also reinforces this hypothesis.
The 1929 Grand Banks tsunami is the only known event generated outside the abovementioned source areas. However, even in this case of a very large landslide triggered by an earthquake, the maximum observed amplitude reached only $13 \mathrm{~cm}$ on the mainland Portuguese coasts.

Among the areas where local events are known, particular attention must be drawn to the Tagus Estuary (TE): it is the site of two well established events (1531 and 1926) and the possible location of a third one (16 November 1755). The two other local events (on Cape Girão and Tavira) have unknown repeatability. In the case of Cape Girão rock fall, the basic characteristics to generate another event apparently persist: steepness and lithology of the cliff, short distance to beaches with human occupation. In the case of Tavira, the existence of previous similar events must still be searched particularly with paleotsunami methods. 


\section{Discussion and conclusions}

The list of tsunamis in the Portuguese coasts includes 17 reliable events since $60 \mathrm{BC}$. Fourteen of them were generated by earthquakes.

A group of five events can be considered as regional or Atlantic wide, and generated important damage: $60 \mathrm{BC}, 382$, 1755, 1761 and 1929. With the exception of the Grand Banks event, all of them were generated by $M>=8$ earthquakes, occurring in large segments of the Eurasia-Nubia plate boundary close to Iberia. They caused inundation of large areas, affected infrastructures close to shore, and the run-out at the harbors destroyed anchored ships. At least in the case of the 1755 tsunami there were many casualties. Morphological changes are claimed for three of them $(60 \mathrm{BC}, 382$ and 1755).

The only tsunami generated far from the plate boundary is the 1929 Grand Banks event, which was caused by a large submarine landslide but its effect on the Portuguese coasts was only detected by tide gauges and even its probable effect on harbors is not documented.

Three events, well recorded by coastal tide gauges in a number of different places (1941, 1969, and 1975), showed moderate wave heights $(<=1 \mathrm{~m})$, with small or negligible inundation effects. The first two were generated in the Gloria Fault Domain, as major strike slip shocks; the third was generated south of the Gorringe Bank, as a thrust, by a $M=8$ earthquake. All showed significant effects in the harbors of the Portuguese mainland, Madeira and/or Azores.

Three events (1531, 1722 and 1926) can be considered local tsunamis: they were generated by small size faults and probably $M<7$ earthquakes, but close enough to the shore to have generated important impact in close areas. A similar situation concerns the 4 March 1930 rock fall in Madeira Island. The importance of local events is particularly high at Algarve (southern Portuguese coast) and at Lisbon estuary, where at least two events are well established (1531 and 1926). A third event (1756) can also be considered to have been generated close to Lisbon, according to the available information. Local tsunamis must be considered in the evaluation of tsunami hazard, particularly in the areas of Algarve and Lisbon. Their origin is seismic but, seen the small magnitudes of some of the earthquakes in cause, the existence of a significant landslide component must be considered. In the case of the 1926 Tagus event, and taking into consideration the low presumed magnitude of the associated earthquake, and the lack of coherent tsunami signal in Cascais tide gauge, out of the Lisbon bar, we consider as the most probable cause an earthquake marine slide in the Estuary.

If we consider the period after $60 \mathrm{BC}$, which is usually the starting date for most earthquake catalogs of Portugal, we can verify that events with magnitude larger than 7.5, and epicenter offshore generated tsunamis. The exceptions are the 29 June 1033 and the 24 August 1356 events (Martins and Victor, 2001) both poorly known.
Small tsunamigenic earthquakes are only known after 1881. Table 2 includes five events observed during the XX Century, with wave amplitudes smaller than $35 \mathrm{~cm}$, thanks to the mareographic network, which allowed the detection of tsunami events with intensities reaching $K \sim I$ in the Papadopoulos-Imamura scale. Before 1881 the detection threshold is larger and only events with $K>2$ or 3 are preserved in written documents.

The new events included in this revision point to the fact that the level of completeness of tsunami catalogs is still low, even if we limit to the instrumentation period (after 1881). Future work must include more historical research, particularly roman sources, and systematic screening of all available mareograms. There is also the need for the evaluation of all naval archives, particularly Portuguese, Spanish, British and French, as naval captains may have kept logs that may have recorded some important events.

Acknowledgements. The present work was made in the framework of work-packages WP1 and WP2 of TRANSFER, Working Group 1 of NEAMTWS - IOC (UNESCO) and benefited from intermediate results of NEAREST project. We thank both principal investigators of TRANSFER and NEAREST Stefano Tinti and Nevio Zitellini for their support during this study and the TRANSFER colleagues Alessandra Maramai and Helene Hebert for sending data not available in Lisbon. We also thank PaulLouis Blanc from the Centre des Faibles Radioactivités, CEA France, for making available some important texts and Fernando Marques for clarifications on the Madeira 1930 event and Domingos Rodrigues for making available the photo presented in Fig. 1. We thank the collaboration of the following institutions: the Gibraltar Garrison Library (Lorna M Swift); the University Archives, Georgetown University (Lynn Conway); The British Association for the Advancement of Science (Rupa Kundu); Instituto Hidrográfico, Portugal (Joana Reis), Instituto Geografico Português (Gonçalo Crisóstomo); the library of Instituto D. Luiz, Portugal (Cristina Domingues), and the Administration Board of the Douro and Leixões harbors. A part of the historical research included here was performed by Salomé Heitor, during GITEC project 1992-1994. Coordinates in Table 1 were obtained from Google Earth.

Edited by: S. Tinti

Reviewed by: S. Haslett and another anonymous referee

\section{References}

Ambraseys, N. N.: Data for the investigation of the seismic seawaves in the Eastern Mediterranean, B. Seismol. Soc. Am., 52, 895-913, 1962.

Ambraseys, N. N.: Intensity Attenuation and Magnitude Intensity Relationships for Northwest European Earthquakes, Earthq. Eng. Struct. D., 13, 733-778, 1985.

Andrade, C.: Tsunami generated forms in the Algarve barrier islands (South Portugal), Science of Tsunami Hazards, 10, 21-34, 1992. 
Andrade, C., Borges, P., and Freitas, M. C.: Historical tsunamis in the Azores Archipelago (Portugal), J. Volcanol. Geoth. Res., 156, 172-185, 2006.

Arquivos do Ministério do Reino: Maço ${ }^{o}$ 638, Documentação sobre o tremor de terra de 1 de Novembro de 1755, ANTT, Arquivo Nacional da Torre do Tombo, Lisboa, Portugal, 1756 (in Portuguese).

Babinet, J.: Note dans les Comptes Rendus de la Académie des Sciences de Paris, LII, 369 pp., 1861 (in French).

Baptista, M. A., Heitor, S., Miranda, J. M., Miranda, P. M. A., and Victor, L. M.: The 1755 Lisbon tsunami: Evaluation of the tsunami parameters, J. Geodyn., 25, 143-157, 1998a.

Baptista, M. A., Miranda, J. M., Chierici, F., and Zitellini, N.: New study of the 1755 earthquake source based on multi-channel seismic survey data and tsunami modeling, Nat. Hazards Earth Syst. Sci., 3, 333-340, 2003,

http://www.nat-hazards-earth-syst-sci.net/3/333/2003/.

Baptista, M. A., Miranda, J. M., Lopes, F. C., and Luís, J. F.: The Source of the 1722 Algarve Earthquake: Evidence from MCS and Tsunami Data, J. Seismol., 11(4), 371-380, 2007.

Baptista, M. A., Miranda, J. M., and Luís, J. F.: In Search of the 31th March 1761 Earthquake and Tsunami Source, B. Seismol. Soc. Am., 96(2), 713-721, 2006.

Baptista, M. A., Miranda, P. M. A., and Victor, L. M.: Maximum entropy analysis of portuguese tsunami data, The tsunamis of 28.02.1969 and 26.05.1975, Science of Tsunami Hazards, 10, 9-20, 1992.

Baptista, M. A., Miranda, P. M. A., Miranda, J. M., and Victor, L. M.: Constrains on the source of the 1755 Lisbon tsunami inferred from numerical modelling of historical data, J. Geodyn., 25, 159-174, 1998b.

Belém, Fr. J.: Chronica Serafica da Santa Província dos Algarves, da Regular Observancia do Nosso Senhor Padre S. Francisco, Em que se trata de sua Origem, Progressos e Fundações de seus Conventos, Parte Primeira, Lisboa, cap. XXII, 200-201, 1750 (in Portuguese).

Bergeron, A. and Bonin, J.: The deep structure of Gorringe Bank (NE Atlantic) and its surrounding area, Geophys. J. Int., 105(2), 491-502, 1991.

Berninghausen, W. H.: Tsunamis and seismic seiches reported from the eastern Atlantic south of the Bay of Biscay, B. Seismol. Soc. Am., 54, 439-442, 1964.

Bewick, B.: An Account of the Earthquake at Cadiz, November 1, 1755, in a Letter from Benjamin Bewick, Merchant there, to Mr. Joseph Paice, Merchant in London, Lett. XIV, for the Year 1756, Philosophical Transactions, Vol. XLIX, Part II, London, 1757.

Borges, J. F., Bezzeghoud, M., Buforn, E., Pro, C., and Fitas, A.: The 1980, 1997 and 1998 Azores earthquakes and some seismotectonic implications, Tectonophysics, 435(1-4), 37-54, 2007.

Borlase, W.: Letter to the Rev. Charles Lytleton, L. L. Dean of Exeter, Lett. XV, printed for L. Davis and C. Reymers, Printers to the Royal Society, against Gray's Inn Gate, in Holbourn, for the Year 1756, Philosophical Transactions, Vol. XLIX, Part II, London 1757, London, 1755.

Borlase, W.: Some Account of the extraordinary Agitation of the Waters in Mount's-bay, and other Places, on the 31st of March 1761, in: A Letter for the Reverend Dr. C Lyttelton, Philos. T. Roy. Soc. 52, 418-431, 1762.
Brito, F. B.: Monarquia Lusitana, Lisboa Imprensa Nacional - Casa da Moeda, Facsimile, 1973-88, 1597.

Buforn, E., Udias, A., and Colombas, M.: Seismicity, source mechanisms and tectonics of the Azores - Gibraltar plate-boundary, Tectonophysics, 152, 89-118, 1988.

Campos, M. L.: El Riesgo de tsunamis en España, Analysis y Valoracion Geografica, Monografia do Instituto Geográfico Nacional, Madrid-Espanha, 1-204, 1992.

Carrilho, F., Nunes, J. C., Pena, J., and Senos, M. L.: Catálogo Sísmico de Portugal Continental e Região Adjacente para o períododo 1970-2000, Instituto de Meteorologia, ISBN 9729083-12-6, 231 pp., 2004.

Castro, D. A. L. F.: Historia Geral de Portugal e suas conquistas, Database Fundo Antigo, Academia de Ciências de Lisboa, Livro 1, Capitulo IV, Manuscript 691, 21-36, 1786 (in Portuguese).

Chambers, C.: Another Account of the Same Earthquake at Madeira in a Letter from Charles Chambers to his Father, in London, dated at Madeira, Novem. I, 1755, Communicated by Lewis Crusius, D. D. F. R. S., Lett. XVIII, for the Year 1756, Philosophical Transactions, Vol. XLIX, Part II, London, 1757.

Codex 8009: Breve notícia de alguns terramotos, Arquivo Nacional da Torre do Tombo, Lisboa, Portugal, no date (in Portuguese).

Codex 9857: Incomplete Reference. Reserved documents of the Lisbon National Library, Lisboa, Portugal, no date (in Portuguese).

Correio dos Açores: Portuguese newspaper published in the Azores the 26 December 1939, 1939 (in Portuguese).

Costa, A., Andrade, C., Seabra, C., Matias, L., Baptista, M. A., and Nunes, S.: 1755, Terramoto no Algarve, Editor Centro de Ciência Viva do Algarve, ISBN 972-99778-0-1, 2005 (in Portuguese).

Couto, D.: Da Ásia, Década 4, Livro 7, Cap XI, Lisboa, 1778 (in Portuguese).

da Silva, F. C.: Theatro Universal de novidades políticas, marciais e elementares e prognósticos para o anno de 1757 , o primeiro depois do bissexto, Calculado ao meu dano da Cidade de Lisboa pela altura de 38 gr e 43 minutos de elevaçam do pólo, Lisboa, oficina de Manoel Soares, 1756 (in Portuguese).

Dabrio, C. J., Zazo, C., Goy, J. L., Sierro, F. J., Borja, F., Lario, J., González, J. A., and Flores, J. A.: Depositional history of estuarine infill during the Late Pleistocene-Holocene postglacial transgression, Mar. Geol., 162, 381-404, 2000.

Dawson, A. G., Hindson, R., Andrade, C., Freitas, C., Parish, R., and Bateman, M.: Tsunami sedimentation associated with the Lisbon earthquake of 1 November AD 1755: Boca do Rio, Algarve, Portugal, The Holocene, 5(2), 209-215, 1995

De la Torre, F. R.: Revisión del Catálogo Sísmico Ibérico (años 1760 a 1800) Estudio realizado para el Instituto Geográfico Nacional, mediante convenio de investigación número 7.070, Madrid, 1997 (in Spanish).

Diário da Manhã: Portuguese Newspaper published 29 March 1969, 1969 (in Portuguese).

Diário de Noticias $n^{\circ} 219876$ : Portuguese newspaper published the 26 December 1926, p. 1, p. 3, 1926 (in Portuguese).

Diário de Noticias da Madeira $n^{\circ} 20368$ : Portuguese newspaper published the 26 November 1941, year 66, 1-2, 1941a (in Portuguese). 
Diário de Notícias da Madeira $\mathrm{n}^{o}$ 20369: Portuguese newspaper published the 27 November 1941, year 66, 1, 1941b (in Portuguese).

Diário dos Açores n²9792: Portuguese newspaper published the 26 May 1975, year 106, 1-2, 1975a (in Portuguese).

Diário dos Açores $n^{\circ} 29793$. Portuguese newspaper published the 27 May 1975, year 106, 1, 1975 b (in Portuguese).

El Mrabet, T.: Tarikh azalazil bi Al Maghrib. Thèse 3 ème cycle. Univ. Md V, Faculté des Lettres et des Sciences Humaines Rabat, 370 pp., 1991 (in Arabic).

Ellicot, J.: Letter to Tilman Henkel, Esq. Merchant in London, concerning the Eartqhuake at Oporto in Portugal, Nov. 1. 1756, Communicated by Mr. John Ellicot, F. R. S., Lett. VIII, for the Year 1756 Philosophical Transactions, Vol. XLIX, Part II,, London 1757.

Fernandes, R. M. S., Miranda. J. M., Meijninger, B. M. L. , Bos, M. S., Noomen, R., Bastos, L., Ambrosius, B. A. C., and Riva, R. E. M.: Surface Velocity Field of the Ibero-Maghrebian Segment of the Eurasia-Nubia Plate Boundary, Geophys. J. Int., 169(1), 315-324, 2007.

Fine, I. V., Rabinovich, A. B., Bornholdd, B. D., Thomson, R. E., and Kulikov, E. A.: The Grand Banks landslide-generated tsunami of November 18, 1929: preliminary analysis and numerical modeling, Mar. Geol., 215, 45-57, 2005.

Freitas, M. P.: A Vaga da Morte. Girão, Revista de Temas Culturais do concelho de Câmara de Lobos, ${ }^{o} 2,1^{o}$ Semestres de 1989, 52-54, 1989 (in Portuguese).

Fukao, Y.: Thrust faulting at a lithosphere plate boundary, The Portugal earthquake of 28.02.1969, Earth Planet. Sc. Lett., 18, 205216, 1973.

Gazeta de Lisboa: Newspaper published in Lisbon, $N^{o} 47$, Biblioteca Nacional de Lisboa, Portugal, 1755 (in Portuguese).

Gibraltar Chronicle: 26 November 1941, Gibraltar Garrison Library, Gibraltar UK, p. 2, 1941a.

Gibraltar Chronicle: 27 November 1941, Gibraltar Garrison Library, Gibraltar UK, p. 3, 1941 b.

Gjevik, B., Pedersen, G., Dybesland, E., Harbitz, C. B., Miranda, P. M. A., Baptista, M. A., Mendes-Victor, L., Heinrich, P., Roche R., and Guesima, M.: Modeling tsunamis from earthquake sources near Gorringe Bank southwest of Portugal, J. Geophys. Res., 102(C13), 27 931-27 949, 1997.

Gracia, E., Dañobeitia, J., Vergés, J., and PARSIFAL Team: Mapping active faults offshore Portugal $\left(36^{\circ} \mathrm{N}-38^{\circ} \mathrm{N}\right)$ : Implications for seismic hazard assessment along the southwest Iberian margin, Geology, 31(1), 83-86, 2002.

Gracia, E., Dañobeitia, J., Vergés, J., Bartolomé, R., and Córdoba, D.: Crustal architecture and tectonic evolution of the Gulf of Cadiz (SW Iberian margin) at the convergence of the Eurasian and African plates, Tectonics, 22(4), 1033, doi: 10.1029/2001TC901045, 2003.

Gutscher, M.-A., Baptista, M. A., and Miranda, J. M.: The Gibraltar Arc seismogenic zone (part 2): constraints on a shallow east dipping fault plane source for the 1755 Lisbon earthquake provided by tsunami modelling and seismic intensity, Tectonophysics, 426, 153-166, doi:10.1016/j.tecto.2006.02.025, 2006.

Haslett, S. K. and Bryant, E. A.: Historic tsunami in Britain since AD 1000: a review, Nat. Hazards Earth Syst. Sci., 8, 587-601, 2008, http://www.nat-hazards-earth-syst-sci.net/8/587/2008/.

Heberden, W.: An account of the Earthquake in the Island of
Madeira, Nov. 1, 1755, in: A Letter from Dr. Tho. Heberden to his brother Dr. William Heberden, F. R. S., Lett. XVII, for the Year 1756, Philosophical Transactions, Vol. XLIX, Part II, London, 1757.

Heck, N. H.: List of Seismic Sea Waves, B. Seismol. Soc. Am., 37(4), 269-284, 1947.

Heinrich, P., Baptista, M. A., and Miranda, P. M. A.: Numerical Simulations of the 1969 Tsunami along the Portuguese coasts, Science of Tsunami Hazards, 12(1), 3-25, 1994.

Hirn, A., Haessler, H., Hoang, T., Wittlinger, G., and MendesVictor, L.: Aftershock Sequence of the January 1, 1980, Earthquake and Present Day Tectonics in the Azores, Geophys. Res. Lett., 7, 501-504, 1980.

IANTT: Instituto do Arquivo Nacional da Torre do Tombo, Dicionário Geográfico, Freguesia de Boliqueime, 7(301), 977-980, 1758 (in Portuguese).

Imamura, F. and Papadopoulos, G.: The tsunami Intensity scale, 2001, International Tsunami Symposium, Seattle, USA, 569577, 2001.

Instituto Geográfico Nacional: Terremotos y Tsunamis in Espana, CD ISBN 84-9810346-O, 2005 (in Spanish).

Journal Historique: Journal Historique sur Les Matières du Tems contenant quelques nouvelles de Litterature, et autres Remarques curieuses, Suite des Tremblements de Terre, p. 462, 1756 (in French).

Journal Historique: Suite de La Clef ou Journal Historique sur Les Matières du Tems, contenant quelques nouvelles de Littérature, et autres Remarques curieuses, Juin 1773, Première Partie, Tome CXIII, Paris 462-464, 1773 (in French).

Justo, J. L. and Salwa, C.: The 1531 Lisbon earthquake, B. Seismol. Soc. Am., 88, 319-328, 1998.

Kaabouben, F., Brahim A. I., Toto E. A., Baptista M. A., Miranda J. M., Soares P., Luis J. F.: On the focal mechanism of the 26.05.1975 North Atlantic event contribution from tsunami modeling, J. Seismol., 12(4), 575-583, doi:10.1007/s10950-0089110-6, 2008.

Lario, J.: Último y Presente Interglacial en el área de conexión Atlántico - Mediterráneo (Sur de España). Variaciones del nivel del mar, paleoclimas y paleoambientes. Ph.D. thesis, Universidad Complutense de Madrid, 269 pp., 1996 (in Spanish).

Levret, A.: The effects of the November 1, 1755 Lisbon earthquake in Morocco, Tectonophysics, 193, 83-94, 1991.

LNEC: A Sismicidade Histórica e a Revisão do Catálogo Sísmico. Proc. 36/11/7368. Laboratório Nacional de Engenharia Civil. Ministério do Equipamento Social, 1986 (in Portuguese).

Lopes, J. B. S.: Corografia ou memória económica do reino do Algarve. Ed. Academia de Ciências Lisboa, 169 pp., 1841 (in Portuguese).

Luque, L., Lario, J., Zazo, C., Goy, J. L., Dabrio, C. J., Silva, P. G.: Tsunami deposits as paleoseismic indicators: examples from the Spanish coast. Acta Geologica Hispanica, 36(3-4), 197-211, 2001.

Luque, L., Lario, J., Silva, P. G., Zazo, G., Goy, J. L., Dabrio, C. J.: Sedimentary record of a tsunami during Roman times, Bay of Cadiz, Spain. Journal of Quaternary Science, 17 (5-6), 623-631, 2002.

Lynnes, C. S., and Ruff, L. J.: Source process and tectonic implications of the great 1975 North Atlantic earthquake, Geophys. J. R. Astr. Soc., 82, 497-510, 1985. 
Mallet, R.: Catalogue of Recorded Earthquakes 1606 B. C. -1850 A. D. Reports on the State of Science. Third Report on the Facts of Earthquake Phenomena, British Assoc., For the Advancement of Science, London, 1852-1854, 1852.

Martins, I. and Victor, L. A. M.: Contribution to the Study of Seismicity in the West Margin of Iberia. Univ Lisboa, IGIDL Pub 25, ISSN 0870-2748, 2001.

Mendonça, J. M.: Historia Universal dos Terramotos que tem havido no mundo de que há noticia desde a sua criação até ao seculo presente, Biblioteca Nacional de Lisboa, Portugal, 272 pp., 1758 (in Portuguese).

Molloy, M.: An Accopunt of the Earthquake in Lisbon 31st March 1761, Philos. T. Roy. Soc., London 1757, 52, 142-143, 1761.

Moreira, V. S.: Tsunamis Observados em Portugal, publicação GEO134. Serviço Meteorológico Nacional, Portugal, 18 pp., (in Portuguese), 1968.

Moreira, V. S.: Sismicidade Histórica de Portugal Continental, Instituto Nacional de Meteorologia e Geofisica, Portugal, 28 pp., 1984 (in Portuguese).

Moreira, V. S.: Review of Historical Seismicity in the Gulf of Cadiz Area before the 1 November 1755 earthquake - A CEC, Project RHISE, annual report, Instituto Nacional de Meteorologia e Geofisica, Portugal, 1991 (in Portuguese).

Murty, T. S. and Loomis, H.: A new objective tsunami magnitude scale, Mar. Geod., 4, 267-282, 1980.

Nozes, J.: O terremoto de 1755: Testemunhos Britânicos, British Historical Society of Portugal, edited by: Lisoptima, 277 pp., ISBN 9729 394,032, 1990.

Oliveira: Syncope Universal Historico em que em brevissima summa, se descrevem, recupiladas, as mais célebres histórias do mundo, $1^{a}$ parte, Manuscript, Reserved Section of the Lisbon National Library, Códice 11 004, Lisboa, Portugal, no date (in Portuguese).

Oliveira, F.: Theatro Lamentavel: Scena Funesta Relaçam Verdadeira do Terramoto do Primeiro de Novembro de 1755 Com a notícia do estrago, que cauzou em Lisboa, e suas vizinhanças, ruina do reino do Algarve e sustos de todo o Portugal, Coimbra, Officina de Francisco de Oliveira, Impressor da Universidade, 21 pp., 1756 (in Portuguese).

Osório, B.: O terramoto de Lisboa de 1531, Separata do Boletim de I classe da Academia das Ciências de Lisboa, Coimbra, 12 pp., 1919 (in Portuguese).

Papadoupolos, G.: Tsunami hazard in the Eastern Mediterranean: strong earthquakes and tsunamis in the Corinth Gulf, central Greece, Nat. Hazards, 29, 437-464, 2003.

Perrey, A.: Sur les tremblements de terre de la Péninsule Ibérique, Annales des sciences physiques et naturelles, d'agriculture et d'industrie, X. Société Royale d'agriculture, d'histoire naturelle et des arts utiles, Lyon, 463-514, 1847 (in French).

Resende, G.: Miscelânia e Variedade de Histórias, Costumes, casos e cousas que em seu tempo aconteceram, edited 1917, Lisboa 1554 (in Portuguese).

Rodigues, D.: Análise do risco do movimentos de vertente e ordenamento do território na Madeira, Aplicação ao caso do Machico, Ph.D. thesis, University of Madeira, Portugal, 2005.

Rodriguez, G.: Catalogo sísmico de a zona compreendida entre los meridianos 5 e $20 \mathrm{~W}$ de Greenwich e los paralelos 45 y 25 N. Imprenta de Romano Velasco, Madrid-Spain, 1932 (in Spanish).
Rosa, J. F. and Fernandes, J. P.: A Vaga da Morte, Tipografia do Diário da Madeira, Funchal, 1930 (in Portuguese).

Runa, L. M. L. F. and Freire, A. G. N. M.: Terramoto de Lisboa de 1 de Novembro de 1755, Grupo de Protecção e Segurança Nuclear, Lisboa, Portugal, 1991 (in Portuguese).

Ruiz, F., Rodríguez-Ramírez, A., Cáceres, L. M., Vidal, J. R., Carretero, M. I., Abada, M., Olías, M., and Pozo, M.: Evidence of high-energy events in the geological record: Mid-holocene evolution of the southwestern Donana National Park (SW Spain), Palaeogeogr. Palaeocl., 229, 212-229, 2005.

Ruiz, F., Abad, M., Vidal, J. R., Caceres, L. M., GonzalezRegalado, M. L., Carretero, M. I., Pozo, M., and Toscano, F. G.: The geological record of the oldest historical tsunamis in southwestern Spain, Rivista Italiana di Paleontologia e Stratigrafia, 114(1), 145-154, 2008.

Sachetti, J. M.: A Copy of Part of Two Letters Written by John Mendes Sacheti, M. D. F. R. S. Dated From the Fields of Lisbon, on the 7th of November, and the 1st of November 1755, Lett. IV, for the Year 1756, Philosophical Transactions, Vol. XLIX, Part II, London, 1757.

Scheffers, A. and Kelletat, D.: Tsunami Relics on the Coastal Landscape West of Lisbon, Portugal, Science of Tsunami Hazards, 23(1), p. 3, 2005.

Solares, J. M. M. and Arroyo, A. L.: The great historical 1755 earthquake. Effects and damage in Spain, J. Seismol., 8, 275 pp., 2004.

Solares, J. M., Lopez-Arroyo, A., and Mezcua, J.: Isoseismal map of the 1755 Lisbon earthquake obtained from Spanish data, Tectonophysics, 53, 301-313, 1979.

Sousa, M. F.: Europa portuguesa segunda edicion correta, ilustrada y añadida en tantos lugares y con tales ventajas que es labor nueva por su autor Manuel de Faria y Sousa, tomo I [-III], printed by: Craesbeeck de Mello, d'Antonio, 1678-1680, Biblioteca Nacional de Lisboa, Portugal, Tomo I 491 pp., Tomo II 224pp., Tomo III 594 pp., 1678 (in Portuguese).

Sousa, F. L. P.: O terremoto do $1^{\circ}$ de Novembro de 1755 em Portugal e um estudo demográfico, Serviços Geológicos, 4 vols., 1-4, 72-73, 403-510, 806-831, 1919 (in Portuguese).

Sousa, M. L., Martins, A., and Oliveira, C. S.: Compilação de ratálogos sísmicos da Região Ibérica, Laboratório Nacional de Engenharia Civil, Lisboa, Rep. 36/92-NDA, 1-250, 1992 (in Portuguese).

Tendorf, F. J.: Seismological Dispatches, University of Georgetown, USA, 1926.

Terrinha, P., Pinheiro, L. M., Henriet, J. P., Matias, L., Ivanov, M. K., Monteiro, J. H., Akhmetzhanov, A., Volkonskaya, A., Cunha, T., Shaskin, P., and Rovere, M.: Tsunamigenicseismogenic structures, neotectonics, sedimentary processes and slope instability on the southwest Portuguese Margin, Mar. Geol., 195(1-4), 55-73, 2003.

Tinti, S., Baptista, M. A., Harbitz, C. B., and Maramai, A.: The unified European catalogue of tsunamis: a GITEC experience, Proc. International Conference on Tsunamis, Paris, 26-28 May 1998, 84-99, 1999.

Tinti, S. and Maramai, A.: Catalogue of tsunamis generated in Italy and in Côte d'Azur, France: a step towards a unified catalogue of tsunamis in Europe, Ann. Geofis., 39, 1253-1299, 1996. 
Tinti, S., Maramai, A., and Graziani, L.: The New Catalogue of Italian Tsunamis, Nat. Hazards, Kluwer Acad. Press, 33, 439465, 2004.

Trembley, A.: An Account of the Earthquake felt at Geneva, Novem. 9. 1755, in a Letter from Mons. Trembley, Professor of Mathematics there, to his Brother Mr. Abraham Trembley, F. R. S. Translated from the French. Lett. XX, for the Year 1756 Philosophical Transactions, Vol. XLIX, Part II, London, 1757.

Urban, S.: The Gentleman's Magazine, printed by: D. Henry, D. and Cave, R., St. John' Gate, London, 554-564, 1755a.

Urban, S.: Supplement to the Gentleman's Magazine for the year 1755, printed by: Henry, D. and Cave, R., St. John' Gate, London, 587-591, 1755b.

Vizcaino, A., Gracia, E., Escutia, C., Asioli, A., Garcia-Orellana, J., Lebreiro., S., Cacho, I., Thouveny, N., Larrasoaña, J. C., Diez, S., and Dañobeitia, J. J.: Characterizing Holocene Paleoseismic Record in the SW Portuguese Margin, Geophys. Res. Abstr., 8, 08 469, SRef-ID: 1607-7962/gra/EGU06-A-08469, 2006.

Vogt, J.: Revision d'Anciens Seismes Ibero-Maghrebins, in: Les Effects du Seisme de Lisbonne du ler Novembre 1755 sur le Territoire Marocain, Esquisse des lntensités Maximales Observdes Dues aux Grands Séismes Ibero-Maghrebins, edited by: Levret, A., Commissariat a l'Energie Atomique, 319 pp., 1985 (in French).
Ward, S. N. and Day, S.: Cumbre Vieja Volcano, Potential collapse and tsunami at La Palma, Canary Islands, Geophys. Res. Lett., 28(17), 3397-3400, 2001.

Zitellini, N., Mendes, L. A., Cordoba, D., Danobeitia, J., Nicolich, R., Pellis, G., Ribeiro, A., Sartori, R., Torelli, L., Bartolome, R., Bortoluzzi, G., Calafato, A., Carrilho, F., Casoni, L., Chierici, F., Corela, C., Correggiari, A., Della Vedova, B., Gracia, E., Jornet, P., Landuzzi, M., Ligi, M., Magagnoli, A., Marozzi, G., Matias, L., Penitenti, D., Rodriguez, P., Rovere, M., Terrinha, P., Vigliotti, L., and Ruiz, A. Z.: Source of 1755 Lisbon earthquake and tsunami investigated, EOS, Nr. 26, 285, 290-291, 2001.

Zitellini, N., Rovere, M., Terrinha, P., Chierici, F., Matias L., and the BIGSETS Team: Neogene through Quaternary tectonic reactivation of SW Iberian passive margin, Pure Appl. Geophys., 161, 565-587, 2004. 